The Effects of Direct Foreign Investment on Domestic Firms: Evidence from Firm Level Panel Data in Emerging Economies

$$
\text { By: Jozef Konings }
$$

Working Paper Number 344

October 2000 


\title{
The Effects of Direct Foreign Investment on Domestic Firms: Evidence from Firm Level Panel Data in Emerging Economies
}

\author{
By Jozef Konings \\ LICOS, Centre for Transition Economics \\ Economics Department \\ Catholic University of Leuven \\ De Beriotstraat 34 \\ 3000 Leuven \\ Belgium \\ Other affiliations: CEPR, London; Dartmouth College, USA \\ Email: jozef.konings@econ.kuleuven.ac.be
}

August 2000

Acknowledgements: This paper is part of a project on DFI in Central and Eastern Europe, funded by the Thyssen foundation. I appreciate comments from Filip Abraham, Lode Berlage, Hans Degryse, Nina Pavnic, Koen Schoors, Hylke Vandenbussche and Reinhilde Veugelers. This paper benefited from seminars at the KULeuven, the University of Gent, the University of Antwerp (Ufsia) and the IMF. I thank Giulia Faggio and Frederic Warzynski for assistance. 


\section{Non-Technical Summary}

The collapse of communism in Central and Eastern Europe and the emergence of a market economy has led to a large inflow of direct foreign investment (DFI) in the region during the last decade and in particular since the mid 90's. Given the enormous increase in foreign investment, these countries provide an ideal natural experiment for measuring the impact of incoming foreign investment on performance. In particular, this paper uses firm level panel data to investigate empirically the effects of DFI on the productivity performance of domestic firms in three emerging economies of Central and Eastern Europe: Bulgaria, Romania and Poland.

To this end a unique data set is used with detailed information on foreign ownership at the firm level. Two main questions are addressed in the present paper: (1) do foreign firms perform better than their domestic counterparts? (2) do foreign firms generate spillovers to domestic firms?

There are various reasons why many policy makers believe DFI is beneficial to their country. A first reason is the need for strategic restructuring in firms in the emerging countries. Most firms in the emerging economies of the former Soviet block were characterised by obsolete machinery and outdated production methods. To compete in a market environment, firms had to improve their efficiency by engaging in strategic restructuring, i.e. updating the equipment and production process. Foreign firms have the technological know-how and finance necessary to update the equipment and bring about such strategic restructuring. Foreign participation in domestic firms has the additional benefit that it can impose an efficient corporate governance in privatized firms, often privatized to insider workers/managers, who might block restructuring. A second important reason why foreign investors are invited to emerging countries rests on the believe that they generate positive 
externalities to the domestic firms through a transfer of know-how and technology. Such spillovers can occur through various channels: the introduction of new products and production processes by foreign firms may benefit domestic firms through the accelerated diffusion of new technology. This could occur through labour turnover or through imitation or other channels. One other channel works through the equilibrating mechanism in the market when liberalization, here the opening up of Central and Eastern Europe to the rest of the world, is implemented.

The positive externalities generated by foreign investors, however, may vanish if the increased competition from foreign firms leads to a reduction in the production of the domestic firm, which may lead to an increase in the average costs of production. In this case a negative competition effect may dominate a positive technological spillover effect. In this paper, the net effect is studied.

Only in Poland, I find that foreign firms perform better than firms without foreign participation. In Bulgaria and Romania, no robust evidence is found of a positive foreign ownership effect. This may be due to the fact that it takes time for firms to restructure and that the effects of restructuring on productivity performance only appear after a few years. Since Bulgaria and Romania are less advanced in the transition process compared to Poland this may be a plausible explanation.

Moreover, for all three countries studied here, I find no evidence of positive spillovers to domestic firms on average. In contrast, on average there are negative spillovers to domestic firms in Bulgaria and Romania, while there are no spillovers to domestic firms in Poland. This suggests a negative competition effect that dominates a positive technology effect. 


\begin{abstract}
This paper uses firm level panel data to investigate empirically the effects of direct foreign investment (DFI) on the productivity performance of domestic firms in three emerging economies of Central and Eastern Europe, Bulgaria, Romania and Poland. To this end a unique firm level panel data set is used with detailed information on foreign ownership at the firm level. Two main questions are addressed in the present paper: (1) do foreign firms perform better than their domestic counterparts? (2) do foreign firms generate spillovers to domestic firms?

The estimation technique in this paper takes potential endogeneity of ownership, spillovers and other factors into account by estimating a fixed effects model using instrumental variables in the general methods of moment technique for panel data.
\end{abstract}

Only in Poland, I find that foreign firms perform better than firms without foreign participation. Moreover, for all three countries studied here, I find no evidence of positive spillovers to domestic firms on average. In contrast, on average there are negative spillovers to domestic firms in Bulgaria and Romania, while there are no spillovers to domestic firms in Poland. This suggests a negative competition effect that dominates a positive technology effect

JEL classification: D24, F14, O52, P31

Keywords: Foreign Investment, Spillovers, Emerging countries, Panel data 


\section{Introduction}

This paper uses firm level panel data to investigate empirically the effects of direct foreign investment (DFI) on the productivity performance of domestic firms in three emerging economies of Central and Eastern Europe, Bulgaria, Romania and Poland. The collapse of communism in Central and Eastern Europe and the emergence of a market economy has led to a large inflow of DFI in the region during the last decade and in particular since the mid 90's. Figure 1 shows the evolution of DFI since 1991 for the three countries that I study in this paper, where the level of DFI is normalized to 1 in 1991 . By 1998 there was almost 10 fold increase in DFI in Bulgaria compared to 1991, for Romania and Poland there was even a 50 and 60 fold increase in DFI by 1998.

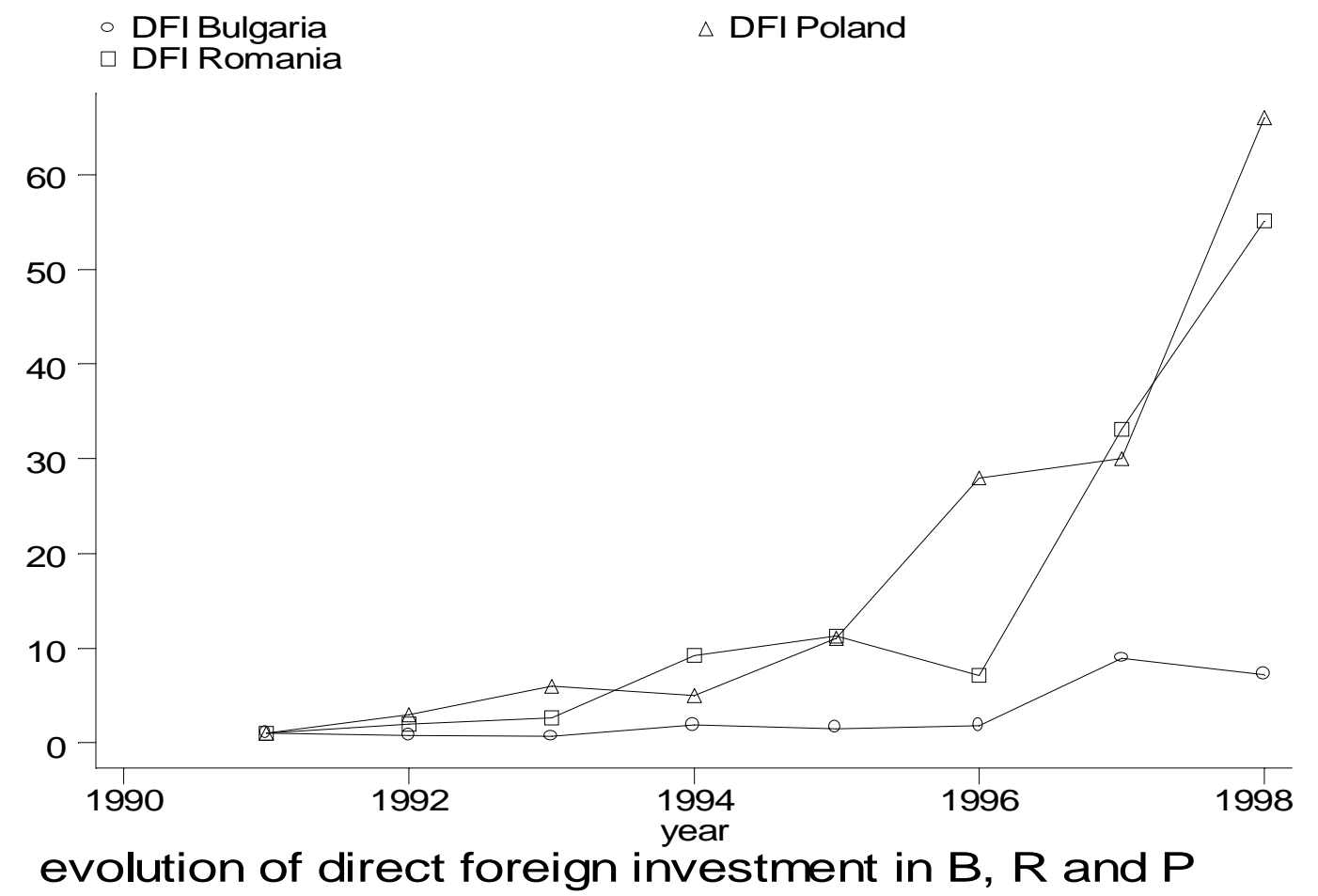

Figure 1 (source: author's calculations based on EBRD (2000)) 
Policy makers in the emerging economies were faced with a collapsing state sector and a slowly growing private sector. With financial markets and commercial banking virtually absent, they encouraged foreign investors to take part in the privatization process or to invest in their countries. Given the enormous increase in foreign investment in these countries as illustrated in figure 1, these countries provide an ideal natural experiment for measuring the impact of incoming foreign investment on performance.

There are various reasons why many policy makers believe DFI is beneficial to their country. A first reason is the need for strategic restructuring in firms in the emerging countries ${ }^{1}$. Most firms in the emerging economies of the former Soviet block were characterised by obsolete machinery and outdated production methods. To compete in a market environment, firms had to improve their efficiency by engaging in strategic restructuring, i.e. updating the equipment and production process (e.g. Irina Grossfeld and Gérard Roland, 1996). Foreign firms have the technological know-how and finance necessary to update the equipment and bring about such strategic restructuring. Foreign participation in domestic firms has the additional benefit that it can impose an efficient corporate governance in privatized firms, often privatized to insider workers/managers, who might block restructuring (Olivier Blanchard, 1997, pp.77-88).

Klaus Wallner (1998) shows theoretically that especially in the emerging countries, characterized by soft budget constraints, foreign investment is welcomed to achieve such strategic restructuring as the presence of foreign investors gives governments incentives to reduce subsidies to firms because otherwise a part of the

\footnotetext{
${ }^{1}$ Strategic restructuring refers to improving the long run viability and efficiency of a firm.
} 
subsidy may disappear in 'foreign pockets'. Hence, the hardening of budget constraints increases effort by managers to restructure more.

A second important reason why foreign investors are invited to emerging countries rests on the believe that they generate positive externalities to the domestic firms through a transfer of know-how and technology. Such spillovers can occur through various channels. David J. Teece (1977) argues that the introduction of new products and production processes by foreign firms may benefit domestic firms through the accelerated diffusion of new technology. This could occur through labour turnover or through imitation or other channels. One other channel works through the equilibrating mechanism in the market when liberalization, here the opening up of Central and Eastern Europe to the rest of the world, is implemented.

A number of recent theoretical papers show that the degree to which domestic firms may benefit from such spillovers depends on the "absorptive capacity" of domestic firms. Franseca Sanna-Randacio (1999) and D. Leahy and Peter Neary (1999) show that DFI always leads to an increase in the productivity of the investing firm, however, DFI increases the host country's productivity only if the degree of the technological spillover is high enough. The latter is more likely achieved in sectors characterized by intensive $R \& D$ or by firms which have a sufficient amount of knowledge to start with.

This has been suggested in earlier empirical work. Ari Kokko (1994) and Borensztein, De Gregorio and Lee (1998) give evidence which suggests that positive DFI spillovers to local firms are only generated if the technology gap between the foreign firm and the domestic one is not too large and if there exists a minimum threshold of human capital in the host country. 
The technological spillovers thus lead to positive effects on domestic firms, however, there may exist a competition effect which works in the opposite direction. Foreign entry disturbs the existing market equilibrium and could force domestic firms to produce less output which pushes them up their average cost curves, at least if average cost curves are downward sloping, which would be the case if production involves a substantial fixed cost. This argument has been developed by Brian J. Aitken and Ann E. Harrison (1999). Which effect dominates depends on the stength of the technological spillover effect (and the absorptive capacity of firms) versus the competition effect.

In this paper I analyse a number of questions: First, I test whether foreign owned subsidiaries in transition economies perform better than their domestically owned counterparts. Second, I test whether there exist 'spillovers' to domestic firms. I will look at the 'net spillover' effect, i.e. the sum of the technological spillover and the competition effect. In addition, I will make a distinction between sectoral and regional spillovers. I also test whether foreign firms benefit from the presence of other foreign firms in their sector or region.

I use a unique panel data set of over 5000 firms in Bulgaria, Romania and Poland for the years 1993-972. Together these countries cover more than 70 million people and hence these economies are an important part of the Central and Eastern European Economies. Bulgaria and Romania are lagging behind Poland in the transition towards a market economy. While all three countries have experienced a substantial collapse in output at the start of transition, only Poland has reached GDP levels comparable to the pre-transition years and has positive growth rates. Both Bulgaria and Romania experienced a short period of positive growth in the mid 90's,

\footnotetext{
${ }^{2}$ except for Romania data run from 1994 onwards.
} 
however, output has collapsed again in Bulgaria since 1995 and in Romania since 1997.

Because I use panel data I am able to track the same firm over time and hence I am able to control for unobserved firm level fixed effects, like for example the quality of the firm. Hence, as in Aitken and Harrison (1999) I am able to control for the potential endogeneity of foreign ownership and spillovers . Moreover, I will use the general methods of moments technique to estimate panel data as introduced by Arellano and Bond (1991) which allows me to construct instruments for potentially endogenous explanatory variables. This may be important if productivity shocks affect the levels of the input variables in a production function or if they affect spillovers. In that case fixed effects alone cannot properly control for the endogeneity. Furthermore, this technique allows me to estimate dynamic equations in a consistent way.

The next section describes the data and econometric approach, section III gives the results and section IV is a concluding one.

\section{Data and Econometric Approach}

\section{Data}

The data set that is used provides information on 2321 firms in Bulgaria between 1993-97, 3844 firms in Romania between 1994-87 and 262 firms in Poland over the period 1993-1997. Due to a lot of missing observations on some of the input factors needed in the estimation, the total available number of firms for the estimation in Poland is much lower than in Bulgaria and Romania. The data are unbalanced panel data, however, attrition is likely to be random due to imperfect reporting, rather 
than exit of firms. The data consists of the company accounts of all incorporated firms in both the manufacturing and the non-manufacturing sectors satisfying at least one of the following criteria: number of employees greater than 100, total assets and operating revenues exceeding 16 million and 8 million USD, respectively. They are retrieved from annual company accounts published by the Creditreform Bulgaria OOD and by the Romanian Chamber of Commerce and Industry ${ }^{\text {旦 }}$.

Foreign firms are defined as firms where a positive fraction of the shares is owned by a foreign investor in 1997 . In the sample, around $10 \%$ of the firms have a foreign investor in 1997. For those firms with a foreign partner, the average fraction of shares held by foreign investors is $61 \%, 59 \%$ and $73 \%$ for Bulgaria, Romania and Poland respectively. Thus if a domestic firm has a foreign investor, on average, the foreign investor has a majority stake.

Econometric Approach and Measurement Issues

I follow Brian Aitken and Ann Harrison (1999) and estimate a log-linear production function at the firm level to test whether (1) foreign firms perform better than domestic ones, (2) there exist spillovers from DFI to local production. In particular, the following specification is the starting point of my analysis:

$y_{i t}=\alpha_{i}+\alpha_{1} n_{i t}+\alpha_{2} k_{i t}+\alpha_{3} m_{i t}+\alpha_{4} \eta_{t}+\alpha_{5} D F I_{i}+\alpha_{6} D F I_{i} X T_{i}+\alpha_{7} S p i l l_{j t}+\varepsilon_{i t}$

\footnotetext{
${ }^{3}$ Data are available on the Amadeus CD-ROM (Dec. 1998), a Pan European financial database, provided by Bureau van Dijk Electronic Publishing SA.
} 
where subscript $\mathrm{i}$ stands for firm $\mathrm{i}$, subscript $\mathrm{t}$ for year $\mathrm{t}, y$ is $\log$ output, $n$ is the $\log$ employment, $k$ is the $\log$ of capital and $m$ is the $\log$ of material inputs. Output is measured as sales at the firm level deflated by an aggregate price index. Sector level price indices were not available on a consistent basis for the countries studied here, so an aggregate producer price index was used for Romania and Poland, an aggregate consumer price index for Bulgaria as there was no reliable producer price index available for Bulgaria. These price indices were taken from the EBRD annual transition report (EBRD, 2000). The capital stock is proxied by the book value of tangible fixed assets in the firm, deflated by an aggregate price index. Finally, material inputs are proxied by material costs have also been deflated by an aggregate price index.

To capture possible common aggregate shocks in production, like technological progress or some other unobserved time varying factors I include time effects, $\eta$. The fraction of shares held by a foreign investor is denoted by DFI. It can be noted that this variable has no time subscript, $t$, which is due to the fact that we only observe ownership in the year 1997. I also interact foreign ownership with the time trend to capture the fact that the effect of foreign ownership might affect both the level and the growth in productivity. This might be the case if it takes some time for foreign know-how to spillover to the local firm. Finally, Spill measures the sector level spillovers that arise from foreign investors. I proxy it by the share of output accounted for by foreign firms in total output at the 2-digit NACE sector level ${ }^{\text {t }}$. I will also report results in which both sectoral and regional spillovers are taken into account. The latter are measured as the fraction of output produced by foreign firms in total output of a particular region. Finally, $\varepsilon$, is a white noise error term.

\footnotetext{
${ }^{4} \mathrm{NACE}$ is the standard European sector classification, which is comparable to the SIC classification.
} 
Table 1 provides summary statistics on the variables that were used in the regression analysis. It can be noted that on average real sales are collapsing in Bulgaria which is consistent with the macro economic decline in GDP since 1995. In contrast, average real sales in Romania are growing rapidly, which is consistent with the fast growth rates in GDP noted since the mid 90's (until 1997, after which output collapsed again). In Poland average real sales are growing at a more modest rate, but the initial 'catch up' took place earlier since transition started earlier in Poland. In absolute terms, the average growth in employment is always lower than the average growth in sales, which confirms the observed aggregate stylized fact that the adjustment in employment is much slower than the adjustment in output. From the summary statistics it can also be noted that the average spillover effect is around $10 \%$, however this may vary substantially between sectors.

In equation (1), there is an unobservable fixed effect, $\alpha_{i}$, which captures firm specific heterogeneity. Such an unobservable fixed effect is potentially correlated with the other explanatory variables. If it is not controlled for in the estimation, then inconsistent estimates due to an omitted variable bias result. One way of controlling for these fixed effects is by first differencing equation (1). At the same time, it is a way to control for potential endogeneity of foreign ownership, i.e. foreign investors might only acquire shares in the better firms. If I categorise firms in 'good' versus 'bad' firms then the unobserved fixed effect captures this and hence it is possible to avoid an endogeneity bias. First differencing equation (1) yields

$$
\Delta y_{i t}=\alpha_{1} \Delta n_{i t}+\alpha_{2} \Delta k_{i t}+\alpha_{3} \Delta m_{i t}+\alpha_{4} \Delta \eta_{t}+\alpha_{6} D F I_{i}+\alpha_{7} \Delta s p i l l_{j t}+\Delta \varepsilon_{i t}
$$


The above modelling strategy allows me to test whether foreign firms perform better and whether spillovers are present. However, equation (2) does not allow me to test whether foreign firms benefit in a different way from spillovers than domestic firms. It may be possible that foreign firms benefit from other foreign firms in their sector, while domestic firms do not as in Aitken and Harrison (1999). For this reason I will include an interaction term in equation (2), where I interact foreign ownership with spillovers.

There is, however, a further econometric concern. An estimation by OLS of equation (2) may still lead to inconsistent estimates. This would be the case if productivity shocks have an effect on the input factors employed in the firm. Alternatively, productivity shocks may have an effect on spillovers, which would lead to an endogeneity of the spillovers. Furthermore, equation (2) is a static equation, allowing for some dynamic adjustment in output (in case of the presence of adjustment costs) would imply that equation (2) needs to be estimated with a lagged dependent variable which leads to further endogeneity problems.

To avoid inconsistent estimates I therefore estimate equation (2) using the General Methods of Moments technique (GMM) with Instrumental Variables as developed by Arellano and Bond (1991) for estimating dynamic panel data. The advantage of this method over other commonly used panel data estimation techniques lies in its efficient use of the number of instruments generated for the endogenous explanatory variables. For instance, in equation (2), valid instruments for the differenced employment in the year 97 is the level of employment in the year 95 since this is not correlated with the differenced error term in 1997. Table 2 shows in a 
systematic way how the number of instruments increases as the panel progresses. In 1995 a valid instrument for a first differenced endogenous explanatory variable is its level in 1993, in 1996 valid instruments for the same variable includes its level in 1993 and its level in 1994 and so on. So as the panel progresses an increasing number of instruments becomes available which increases the efficiency of the estimation. In order to test the validity of instruments a Sargan test of instrument validity is computed and is asymptotically $\chi 2$ distributed. In addition, since the equation is estimated in first differenced form, the equation will show first-order serial correlation. However, what matters is the absence of second order serial correlation if the error term in the levels equation (1) is white noise. Therefore a test of second order serial correlation is reported and is asymptotically $\mathrm{N}(0,1)$ distributed.

\section{Results}

Tables 3, 4 and 5 show the results for Bulgaria, Romania and Poland respectively. I show both OLS estimates and GMM IV estimates for equation (2). Since the equation is estimated in first-differences I also control for unobserved fixed effects.

Starting with Bulgaria, the OLS estimates in column (1) of table 3 show no statistically significant effect of foreign ownership on performance. This may come across as a surprising result, however, in the context of transition economies it has been shown that privatised firms do not perform better than state owned enterprises, because it may take time before restructuring feeds through on firm performance (e.g. Konings, 1997; Faggio and Konings, 1999). There is however a statistically significant negative spillover effect of foreign firms on domestic ones, which suggests 
that a competition effect is dominating a technological spillover effect. The interaction term, foreign $\mathrm{X}$ spillover, suggests that foreign firms benefit from the presence of other foreign firms in the sector. However, this equation does not take into account the potential endogeneity of spillovers and of the other input factors.

In the second column I therefore instrument all the input factors as well as the spillover effect using the moment restrictions suggested by the GMM technique (Arellano and Bond, 1991). A number of interesting results emerge. First, there still exist negative spillovers from DFI to domestic firms. The coefficient that is estimated with spillovers is equal to -0.67 . Thus, a sector that has an increase in spillovers from 0 to $10 \%$ would experience a decline in total factor productivity of $6.7 \%$ on average. This suggests that the competition effect is dominating, which means that domestic firms, due to the increased competition from foreign firms in their sector, are pushed up their average cost curves due to a reduction in output they can produce. This would hold in case domestic firms have a declining average cost curve, i.e. in the presence of increasing returns to scale. Based on the estimates of the coefficients of the input factors, this hypothesis seems to be plausible. The sum of the coefficients of the input factors is larger than 1 which suggests increasing returns to scale in production or a declining average cost curve. Note, also that the coefficient on capital is low and statistically not significant at conventional levels. In the context of transition economies this is not surprising as most firms are characterised by outdated equipment and a lack of investment in new equipment, which decreases the marginal productivity of capital.

A second result, which is the same as in the OLS estimation, is that foreign firms do not outperform domestic ones. Finally, the interaction effect between foreign ownership and spillovers is no longer statistically significant, albeit still positive. 
These IV results suggest that endogeneity may have been important in driving some of the results in the OLS regression. The Sargan test and the second order serial correlation test in collumn (2) all indicate that the model is correctly specified. The fact that there is no second order serial correlation suggests that there is no further dynamics to be specified in the model.

The third column tests whether regional spillovers may matter. As argued by Aitken and Harrison (1999) there may be reasons to expect that any benefits to domestic firms from foreign ivestment would be received first by their neighbors before they diffuse to other domestic firms. One mechanism through which this may occur is through job mobility. Workers who worked with a multinational that leave the firm to work in a domestic one are more likely to move to another firm within the same region. Job reallocation in transition countries (and elsewhere) occurs primarily within regions rather than across regions (e.g. Faggio and Konings, 1999). I measure regional spillovers as the fraction of output produced by foreign firms in a given region in the total output produced by a given region. The results in column (3), however, show no statistically significant effect of regional spillovers to domestic firms in Bulgaria. Since Bulgaria is a small open economy regional effects are presumably less important in terms of competition, rather the entire Bulgarian market is more likely to be the appropriate market to consider.

The results for Romania are reported in table 4 and are very similar to the results for Bulgaria, except that there is some hidden dynamics which needs to be taken into account. In column (1) the OLS results suggest that foreign firms outperform domestic ones, that domestic firms experience positive spillovers and that foreign firms do not benefit from other foreign firms in their sector that much as domestic ones. However, the second order serial correlation test suggests that the 
model is not correctly specified in terms of the dynamics. In addition, there may also be an endogeneity problem related to some of the explanatory variables.

In column (2) of table 4 I therefore report the results using instruments for the input factors and for the spillovers. The results of column (2) show no statistically significant effects of spillovers and foreign ownership. However, again the diagnostics suggest that the model is misspecified, i.e. the Sargan test of instrument validity and the second order serial correlation test reject the model specification. Column (3) therefore estimates a dynamic model, including the lagged dependent variable as one of the regressors. Since the model is estimated in first differences, the lagged dependent variable is also endogenous and therefore needs to be instrumented too, using all available moment restrictions from t-2 backwards. In column (3) the Sargan test accepts the model specification, the second order serial correlation test could no longer be computed since one time observation is lost due to the lagged dependent variable and the fact that the data for Romania only go from 1994 onwards, rather than 1993. However, since the lagged dependent variable is statistically significant, it is likely that this controls for the initial problem of second order serial correlation. The results indicate that spillovers from foreign firms to domestic ones are negative. The results in column (3) suggest that once properly controlled for the dynamics in the model, again the same negative spillover effects show up. The interaction effect between foreign firms and spillovers is no longer statistically significant, just like foreign ownership in itself is no longer statistically significant. This is consistent with the empirical literature that has shown that privatisation did not lead to better firm performance and that it may take some time before firms start to engage in restructuring. 
Finally, in column (4) I test for the presence of regional spillovers. As in Bulgaria, I find no statistically significant effect of regional spillovers on domestic firms.

Table 5 shows the results for Poland. Since I lost a lot of observations in the estimation due to missing data on material costs, the Polish sample is much smaller than the one used for Bulgaria and Romania, so the results for Poland need to be read with caution. The first column gives the OLS results. I find a statistically significant effect of foreign ownership on firm productivity performance. This contrasts with Bulgaria and Romania where I found no effect of foreign ownership. In the case of Poland, however, it may make sense that foreign firms outperform domestic ones since Poland is in a more advanced stage of development towards a market economy. If it takes time for firms to restructure then one may expect that in less developed countries, such as Bulgaria and Romania, foreign firms do not outperform domestic ones, while in the more advanced ones, such as Poland, the restructuring effects have come through which is reflected in the positive effect of foreign ownership. In column (1) I find no statistically significant effect of spillovers.

In column (2) I report the GMM IV estimates. The same results hold as in the OLS case, i.e. foreign firms outperform domestic ones or to put it differently, a firm that would change its ownership structure from $0 \%$ foreign participation to $100 \%$ foreign participation, total factor productivity would increase by approximately $20 \%$. This result confirms the hypothesis that foreign firms or joint ventures have some superior knowledge and/or technology which allows them to be more efficient than their domestic counterparts. It is also consistent with the idea that foreign firms induce restructuring at the firm level which leads to higher productivity (Wallner, 1998). 
Again I find no statistically significant effect of spillovers. This may be due to the fact that the "technological" positive externality and the negative competition effect cancel eachother out, or, it may be due to the fact that there are no increasing returns to scale which would imply that there is no declining average cost curve. The latter makes sense, based on the estimates of the coefficients of the input factors. Rather decreasing returns to scale seem to hold on average, with the only statistically significant input factor being material costs. This is plausible as most firms in transition countries are still characterised by over-manning levels and an outdated capital stock. Moreover, since transition has started earlier in Poland than in Romania and Bulgaria, the initial increase in competitive pressure at the start of transition was experienced at an earlier stage, such that the competition effect in the case of Poland is likely to be much lower than in the case of Bulgaria and Romania.

Finally, in column (3) I also test for the presence of regional spillovers. However, the only significant effect I find is the material costs of production. Also foreign ownership is no longer statistically significant at conventional levels. This is most likely due to multicollinearity of the data, given that only 262 observations are used in the estimation. For this reason I estimated the equation again, but leaving out the interaction terms between foreign ownership and spillovers. In column (4) the results are reported and show that as before foreign firms do better than domestic ones. In addition, I find evidence of negative regional spillovers, albeit only significant at the $10 \%$ level, but still no evidence of spillovers at the sectoral level. 


\section{Conclusion}

This paper studied the effects of direct foreign investment on the performance of firms in three emerging market economies, Bulgaria, Romania and Poland. Two main questions were addressed. First, do foreign firms perform better than their domestic competitors and second, does foreign investment generate 'spillovers' to local firms?

I find evidence that foreign firms do not perform better than domestic ones, except in Poland, the more advanced transition economy. This suggests that it may take time for ownership effects to have an effect on performance, due to lags in restructuring. In addition, I find no evidence of positive spillovers, but rather negative or no spillovers of foreign investment to domestic firms. This is rationalised through a competition effect that dominates a technological spillover effect in Bulgaria and Romania, which would hold under the assumption of increasing returns to scale (declining average cost curves). The competition effect may dominate the technology effect if the technology gap is too large, which would be the case in less advanced countries such as Bulgaria and Romania.

The results in this paper suggest that in the early stages of transition, the stages Bulgaria and Romania are in, the increased competition from DFI dominates technological spillovers to domestic firms. It suggests that inefficient firms will loose market share due to foreign competition, which in the long run should increase the overall efficiency of an economy. In the latter stages, when domestic firms have engaged in substantial restructuring and market competition has been established, the dominating competition effect seems to vanish. Whether in the longer run 
technological spillover effects start dominating, leading to positive spillovers is a topic for future research when more years of data will become available. 


\section{References}

Aitken, Brian, J. and Harrison, Ann E. (1999). "Do Domestic Firms Benefit from Direct Foreign Investment? Evidence from Venezuela", American Economic Review, Vol. 89, No 3, pp. 605-618.

Arellano, M. and Bond, S. (1991). "Some Tests of Specifications of Panel Data: Monte Carlo Evidence and an Application to Employment Equations", Review of Economic Studies, Vol. 58, pp. 277-94.

Blanchard, Olivier (1997). The Economics of Post-Communist Transition, Clarendon Lectures in Economics, Oxford University Press.

Blomström, Magnus and Sjöholm, Fredrik (1999). “Technology Transfer and Spillovers: Does Local Participation with Multinationals Matter?", European Economic Review, Vol. 43, pp.915-923.

Borensztein, E., De Gregorio, J. and Lee, J-W. (1998). "How Does Foreign Direct Investment Affect Economic Growth?", Journal of International Economics, Vol. 45, pp. 115-135.

Cassiman, Bruno and Veugelers, Reinhilde. (1999). "Spillovers and R\&D Cooperation: Some Empirical Evidence", mimeo KULeuven.

Davis, Steve and Haltiwanger, John (1992). "Gross Job Creation, Gross Job Destruction and Employment Reallocation", Quarterly Journal of Economics, Vol. CVII, pp. 819-863.

Djankov, S. and Hoekman, B. (1998). "Avenues of Technology Transfer: Foreign Investment and Productivity Change in the Czech Republic", CEPR discussion paper 1883.

EBRD (2000). EBRD Transition Report, EBRD, London.

Faggio, G. and Konings, J. (1999). "Gross Job Flows and Firm Growth in Transition Countries: Evidence using Firm Level Data on Five countries", CEPR Discussion Paper, 2261.

Grossfeld, Irina and Roland, Gérard. (1996). "Defensive and Strategic Restructuring in Central European Enterprises", Centre for Economic Policy Research DP 1135.

Kokko, Ari (1994). "Technology, Market Characteristics and Spillovers", Journal of Development Economics, Vol. 43, pp. 279-293.

Konings, Jozef (1997). "Firm Growth and Ownership", Economics Letters, Vol. 55, pp. 413-18.

Leahy, D. and Neary, P. (1999). "Absorptive Capacity, R\&D spillovers, and Public Policy", mimeo University College Dublin. 
Levinsohn, James (1999). "Employment Responses to International Liberalization in Chile", Journal of International Economics, Vol. 47, pp. 321-344.

Repkine, Alexandre and Walsh, Patrick P. (1999). "Evidence of European Trade and Investment U-Shaping Industrial Output in Bulgaria, Hungary, Poland and Romania", Journal of Comparative Economics, December.

Sanna-Randaccio, Fransesca (1999). "The Impact of Foreign Direct Investment on Home and Host Countries with Endogenous R\&D", mimeo Universita' di Roma "La Sapienza".

Teece, David, J. (1977). “Technology Transfer by Multinational Firms: The Resource Cost of Transferring Technological Know-How", Economic Journal, June, Vol 87 (346), pp.242-61.

Wallner, Klaus (1998) "FDI, Soft Budget Constraints and Expropriation Incentives", Mimeo SITE, Stockholm School of Economics. 
Table 1: Summary Statistics (means of the sample)

\begin{tabular}{|l|c|c|c|}
\hline & Bulgaria & Romania & Poland \\
\hline sectoral spillover & 0.09 & 0.13 & 0.15 \\
\hline regional spillover & 0.10 & 0.11 & 0.12 \\
\hline sales growth & -0.27 & 0.47 & 0.07 \\
\hline employment growth & -0.039 & -0.042 & -0.01 \\
\hline capital growth & -0.287 & 0.10 & 0.03 \\
\hline material growth & -0.25 & 0.50 & 0.03 \\
\hline
\end{tabular}

Table 2: Available instruments in GMM technique

\begin{tabular}{|l|c|c|}
\hline & Endogenous explanatory variable & Available instruments \\
\hline $\mathbf{1 9 9 7}$ & $\Delta x_{i 97}$ & $x_{i 95}, x_{i 94}, x_{i 93}$ \\
\hline $\mathbf{1 9 9 6}$ & $\Delta x_{i 96}$ & $x_{i 94}, x_{i 93}$ \\
\hline $\mathbf{1 9 9 5}$ & $\Delta x_{i 95}$ & $x_{i 93}$ \\
\hline
\end{tabular}

Note: $x$ refers to any of the explanatory variables that is treated as endogenous. 
Table 3: Results for Bulgaria

Dependent variable: $y$

\begin{tabular}{|l|c|c|c|}
\hline $\begin{array}{l}\text { independent } \\
\text { variables: }\end{array}$ & OLS & IV & IV \\
\hline $\mathrm{n}$ & $\begin{array}{l}0.127^{*} \\
(0.038)\end{array}$ & $\begin{array}{c}0.538^{*} \\
(0.175)\end{array}$ & $\begin{array}{l}0.560^{*} \\
(0.187)\end{array}$ \\
\hline $\mathrm{k}$ & $0.047^{*}$ & 0.012 & 0.018 \\
& $(0.011)$ & $(0.038)$ & $(0.039)$ \\
\hline $\mathrm{m}$ & $0.626^{*}$ & $0.720^{*}$ & $0.738^{*}$ \\
& $(0.023)$ & $(0.072)$ & $(0.075)$ \\
\hline DFI & -0.03 & -0.112 & -0.176 \\
& $(0.026)$ & $(0.113)$ & $(0.136)$ \\
\hline sector spill & $-0.206^{*}$ & $-0.670^{*}$ & $-0.678^{*}$ \\
& $(0.091)$ & $(0.360)$ & $(0.371)$ \\
\hline DFI x sector spill & $3.528^{*}$ & 6.199 & 5.225 \\
& $(1.473)$ & $(12.184)$ & $(12.40)$ \\
\hline Region spill & - & - & -0.175 \\
& & & $(0.206)$ \\
\hline DFI x region spill & - & - & 5.061 \\
& & & $(5.825)$ \\
\hline Sargan Test & - & $31.18(\mathrm{df}=31)$ & $30.1(\mathrm{df}=29)$ \\
\hline SOC test & 0.248 & -0.103 & -0.025 \\
\hline number of & 4,662 & 4,662 & 4,662 \\
observations & & & \\
\hline Notes: (i) all equat & & & \\
\hline
\end{tabular}

Notes: (i) all equations include time dummies, (ii) heteroscedastic consistent standard errors in brackets, (iii) * denotes significant at the $5 \%$ level, ** at the $10 \%$ level, (iv) instruments include some or all available moment restrictions of the endogenous explanatory variables as well as region dummies. 
Table 4: Results for Romania

Dependent variable: y

\begin{tabular}{|l|c|c|c|c|}
\hline $\begin{array}{l}\text { independent } \\
\text { variables: }\end{array}$ & OLS & IV & IV & IV \\
\hline yt-1 & - & - & $0.138^{*}$ & $\begin{array}{c}0.144^{*} \\
(0.034)\end{array}$ \\
\hline $\mathrm{n}$ & $0.134^{*}$ & $0.245^{*}$ & $0.106^{*}$ & $0.094^{* *}$ \\
& $(0.017)$ & $(0.073)$ & $(0.06)$ & $(0.063)$ \\
\hline $\mathrm{k}$ & $0.081^{*}$ & $0.04^{* *}$ & $0.043^{*}$ & $0.043^{*}$ \\
& $(0.011)$ & $(0.026)$ & $(0.02)$ & $(0.02)$ \\
\hline $\mathrm{m}$ & $0.604^{*}$ & $0.660^{*}$ & $0.411^{*}$ & $0.421^{*}$ \\
& $(0.017)$ & $(0.036)$ & $(0.04)$ & $(0.044)$ \\
\hline DFI & $0.01^{*}$ & 0.04 & 0.001 & 0.128 \\
& $(0.002)$ & $(0.003)$ & $(0.02)$ & $(0.17)$ \\
\hline sector spill & $0.201^{*}$ & 0.436 & $-1.101^{*}$ & $-0.934^{* *}$ \\
& $(0.083)$ & $(0.459)$ & $(0.528)$ & $(0.579)$ \\
\hline DFI x sector spill & $-32.52^{*}$ & -8.937 & -21.06 & -14.8 \\
& $(12.1)$ & $(12.07)$ & $(66.92)$ & $(72.5)$ \\
\hline Region spill & - & - & - & 0.063 \\
& & & & $(0.128)$ \\
\hline DFI x region spill & - & - & -2.93 \\
& & & & $(4.18)$ \\
\hline Sargan Test & - & $15.14(\mathrm{df}=6)$ & $60.3(\mathrm{df}=45)$ & $59.27(\mathrm{df}=43)$ \\
\hline SOC test & -3.708 & -3.872 & - & - \\
\hline number of & 10,955 & 10,955 & 7,111 & 7,111 \\
observations & & & & \\
\hline
\end{tabular}

Notes: as in table 3 
Table 5: Results for Poland

Dependent variable: y

\begin{tabular}{|l|c|c|c|c|}
\hline $\begin{array}{l}\text { independent } \\
\text { variables: }\end{array}$ & OLS & IV & IV & IV \\
\hline $\mathrm{n}$ & $\begin{array}{c}0.01 \\
(0.14)\end{array}$ & $\begin{array}{c}0.022 \\
(0.121)\end{array}$ & $\begin{array}{c}0.062 \\
(0.108)\end{array}$ & $\begin{array}{c}0.03 \\
(0.11)\end{array}$ \\
\hline $\mathrm{k}$ & 0.017 & 0.017 & 0.059 & 0.06 \\
& $(0.03)$ & $(0.087)$ & $(0.083)$ & $(0.067)$ \\
\hline $\mathrm{m}$ & $0.429^{*}$ & $0.487^{*}$ & $0.613^{*}$ & $0.527^{*}$ \\
& $(0.081)$ & $(0.129)$ & $(0.094)$ & $(0.079)$ \\
\hline DFI & $0.178^{*}$ & $0.215^{*}$ & 0.13 & $0.145^{*}$ \\
& $(0.08)$ & $(0.097)$ & $(0.11)$ & $(0.062)$ \\
\hline sector spill & -0.253 & 0.174 & -0.191 & -0.172 \\
& $(0.324)$ & $(0.790)$ & $(0.689)$ & $(0.721)$ \\
\hline DFI x sector spill & 1.14 & 3.175 & -1.84 & - \\
& $(2.162)$ & $(4.835)$ & $(8.34)$ & $-0.48^{* *}$ \\
\hline Region spill & - & - & -0.377 & $(0.301)$ \\
\hline DFI x region spill & - & - & $(0.327)$ & - \\
& & & $(1.77$ & $16.84)$ \\
\hline Sargan Test & - & $12.77(\mathrm{df}=16)$ & $19.03(\mathrm{df}=20)$ & $16.92(\mathrm{df}=21)$ \\
\hline SOC test & 0.171 & 0.536 & 0.07 & 0.391 \\
\hline number of & 340 & 340 & 340 & 340 \\
observations & & & & \\
\hline
\end{tabular}

Notes: as in table 3 


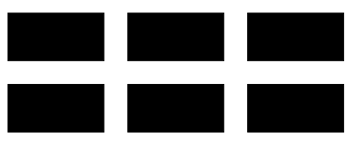

THE WILLIAM DAVIDSON INSTITUTE

AT THE UNIVERSITY OF MICHIGAN BUSINESSSCHOOL

\section{DAVIDSON INSTITUTE WORKING PAPER SERIES}

CURRENT AS OF 11/06/00

\begin{tabular}{|c|c|c|}
\hline Publication & Authors & Date of Paper \\
\hline $\begin{array}{l}\text { No. } 344 \text { The Effects of Direct Foreign } \\
\text { Investment on Domestic Firms }\end{array}$ & Jozef Konings & October 2000 \\
\hline $\begin{array}{l}\text { No. } 343 \text { On the Identification of Relative } \\
\text { Wage Rigidity Dynamics }\end{array}$ & Patrick A. Puhani & October 2000 \\
\hline $\begin{array}{l}\text { No. } 342 \text { The Determinants of Foreign Direct } \\
\text { Investment in Transition Economies }\end{array}$ & Alan A. Bevan and Saul Estrin & October 2000 \\
\hline $\begin{array}{l}\text { No. } 341 \text { The Global Spread of Stock } \\
\text { Exchanges, } 1980-1998\end{array}$ & Klaus Weber and Gerald F. Davis & October 2000 \\
\hline $\begin{array}{l}\text { No. } 340 \text { The Costs and Benefits of Euro- } \\
\text { isation in Central-Eastern Europe Before or } \\
\text { Instead of EMU Membership }\end{array}$ & D. Mario Nuti & October 2000 \\
\hline No. 339 Debt Overhang and Barter in Russia & $\begin{array}{l}\text { Sergei Guriev, Igor Makarov and Mathilde } \\
\text { Maurel }\end{array}$ & September 2000 \\
\hline $\begin{array}{l}\text { No. } 338 \text { Firm Performance and the Political } \\
\text { Economy of Corporate Governance: Survey } \\
\text { Evidence for Bulgaria, Hungary, Slovakia and } \\
\text { Slovenia }\end{array}$ & Patrick Paul Walsh and Ciara Whela & July 2000 \\
\hline No. 337 Investment and Instability & Nauro F. Campos and Jeffrey B. Nugent & May 2000 \\
\hline $\begin{array}{l}\text { No. } 336 \text { The Evolution of the Insurance } \\
\text { Sector in Central and Eastern Europe and } \\
\text { the former Soviet Union }\end{array}$ & Robert B.K. Pye & August 2000 \\
\hline $\begin{array}{l}\text { No. } 335 \text { Institutional Technology and the } \\
\text { Chains of Trust: Capital Markets and } \\
\text { Privatization in Russia and the Czech } \\
\text { Republic }\end{array}$ & Bruce Kogut and Andrew Spicer & August 2000 \\
\hline $\begin{array}{l}\text { No. } 334 \text { The Evolution of Market Integration } \\
\text { in Russia }\end{array}$ & Daniel Berkowitz and David N. DeJong & August 2000 \\
\hline $\begin{array}{l}\text { No. } 333 \text { Efficiency and Market Share in } \\
\text { Hungarian Corporate Sector }\end{array}$ & László Halpern and Gábor Körösi & July 2000 \\
\hline $\begin{array}{l}\text { No. } 332 \text { Search-Money-and-Barter Models of } \\
\text { Financial Stabilization }\end{array}$ & S.I. Boyarchenko and S.Z. Levendorskii & July 2000 \\
\hline $\begin{array}{l}\text { No. } 331 \text { Worker Training in a Restructuring } \\
\text { Economy: Evidence from the Russian } \\
\text { Transition }\end{array}$ & $\begin{array}{l}\text { Mark C. Berger, John S. Earle and Klara } \\
\text { Z. Sabirianova }\end{array}$ & August 2000 \\
\hline $\begin{array}{l}\text { No. 330 Economic Development in Palanpur } \\
\text { 1957-1993: A Sort of Growth }\end{array}$ & Peter Lanjouw & August 2000 \\
\hline $\begin{array}{l}\text { No. } 329 \text { Trust, Organizational Controls, } \\
\text { Knowledge Acquisition from the Foreign } \\
\text { Parents, and Performance in Vietnamese } \\
\text { International Joint Ventures }\end{array}$ & $\begin{array}{l}\text { Marjorie A. Lyles, Le Dang Doanh, and } \\
\text { Jeffrey Q. Barden }\end{array}$ & June 2000 \\
\hline $\begin{array}{l}\text { No. } 328 \text { Comparative Advertising in the } \\
\text { Global Marketplace: The Effects of Cultural } \\
\text { Orientation on Communication }\end{array}$ & $\begin{array}{l}\text { Zeynep Gürhan-Canli and Durairaj } \\
\text { Maheswaran }\end{array}$ & August 2000 \\
\hline $\begin{array}{l}\text { No. } 327 \text { Post Privatization Enterprise } \\
\text { Restructuring }\end{array}$ & Morris Bornstein & July 2000 \\
\hline No. 326 Who is Afraid of Political Instability? & Nauro F. Campos and Jeffrey B. Nugent & July 2000 \\
\hline
\end{tabular}

Working Papers are available at: www.wdi.bus.umich.edu 


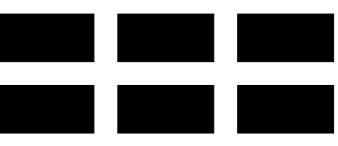

THE WILLIAM DAVIDSON INSTITUTE AT THE UNIVERSITY OF MICHIGAN BUSINESSSCHOOL

\begin{tabular}{|c|c|c|}
\hline $\begin{array}{l}\text { No. } 325 \text { Business Groups, the Financial } \\
\text { Market and Modernization }\end{array}$ & Raja Kali & June 2000 \\
\hline $\begin{array}{l}\text { No. } 324 \text { Restructuring with What Success? A } \\
\text { Case Study of Russian Firms }\end{array}$ & Susan Linz & July 2000 \\
\hline $\begin{array}{l}\text { No. } 323 \text { Priorities and Sequencing in } \\
\text { Privatization: Theory and Evidence from the } \\
\text { Czech Republic }\end{array}$ & $\begin{array}{l}\text { Nandini Gupta, John C. Ham and Jan } \\
\text { Svejnar }\end{array}$ & May 2000 \\
\hline $\begin{array}{l}\text { No. } 322 \text { Liquidity, Volatility, and Equity } \\
\text { Trading Costs Across Countries and Over } \\
\text { Time }\end{array}$ & $\begin{array}{l}\text { Ian Domowitz, Jack Glen and Ananth } \\
\text { Madhavan }\end{array}$ & March 2000 \\
\hline $\begin{array}{l}\text { No. } 321 \text { Equilibrium Wage Arrears: } \\
\text { Institutional Lock-In of Contractual Failure in } \\
\text { Russia }\end{array}$ & John S. Earle and Klara Z. Sabirianova & October 2000 \\
\hline $\begin{array}{l}\text { No. } 320 \text { Rethinking Marketing Programs for } \\
\text { Emerging Markets }\end{array}$ & Niraj Dawar and Amitava Chattopadhyay & June 2000 \\
\hline $\begin{array}{l}\text { No. } 319 \text { Public Finance and Low Equilibria in } \\
\text { Transition Economies; the Role of Institutions }\end{array}$ & Daniel Daianu and Radu Vranceanu & June 2000 \\
\hline $\begin{array}{l}\text { No. } 318 \text { Some Econometric Evidence on the } \\
\text { Effectiveness of Active Labour Market } \\
\text { Programmes in East Germany }\end{array}$ & Martin Eichler and Michael Lechner & June 2000 \\
\hline $\begin{array}{l}\text { No. } 317 \text { A Model of Russia's "Virtual } \\
\text { Economy" }\end{array}$ & R.E Ericson and B.W Ickes & May 2000 \\
\hline $\begin{array}{l}\text { No. } 316 \text { Financial Institutions, Financial } \\
\text { Contagion, and Financial Crises }\end{array}$ & Haizhou Huang and Chenggang $\mathrm{Xu}$ & March 2000 \\
\hline $\begin{array}{l}\text { No. } 315 \text { Privatization versus Regulation in } \\
\text { Developing Economies: The Case of West } \\
\text { African Banks }\end{array}$ & $\begin{array}{l}\text { Jean Paul Azam, Bruno Biais, and } \\
\text { Magueye Dia }\end{array}$ & February 2000 \\
\hline $\begin{array}{l}\text { No. } 314 \text { Is Life More Risky in the Open? } \\
\text { Household Risk-Coping and the Opening of } \\
\text { China's Labor Markets }\end{array}$ & John Giles & April 2000 \\
\hline $\begin{array}{l}\text { No. } 313 \text { Networks, Migration and Investment: } \\
\text { Insiders and Outsiders in Tirupur's Production } \\
\text { Cluster }\end{array}$ & Abhijit Banerjee and Kaivan Munshi & March 2000 \\
\hline $\begin{array}{l}\text { No. } 312 \text { Computational Analysis of the Impact } \\
\text { on India of the Uruguay Round and the } \\
\text { Forthcoming WTO Trade Negotiations }\end{array}$ & $\begin{array}{l}\text { Rajesh Chadha, Drusilla K. Brown, Alan } \\
\text { V. Deardorff and Robert M. Stern }\end{array}$ & March 2000 \\
\hline $\begin{array}{l}\text { No. } 311 \text { Subsidized Jobs for Unemployed } \\
\text { Workers in Slovakia }\end{array}$ & Jan. C. van Ours & May 2000 \\
\hline $\begin{array}{l}\text { No. } 310 \text { Determinants of Managerial Pay in } \\
\text { the Czech Republic }\end{array}$ & $\begin{array}{l}\text { Tor Eriksson, Jaromir Gottvald and Pavel } \\
\text { Mrazek }\end{array}$ & May 2000 \\
\hline $\begin{array}{l}\text { No. } 309 \text { The Great Human Capital } \\
\text { Reallocation: An Empirical Analysis of } \\
\text { Occupational Mobility in Transitional Russia }\end{array}$ & Klara Z. Sabirianova & October 2000 \\
\hline $\begin{array}{l}\text { No. } 308 \text { Economic Development, Legality, } \\
\text { and the Transplant Effect }\end{array}$ & $\begin{array}{l}\text { Daniel Berkowitz, Katharina Pistor, and } \\
\text { Jean-Francois Richard }\end{array}$ & February 2000 \\
\hline $\begin{array}{l}\text { No. } 307 \text { Community Participation, Teacher } \\
\text { Effort, and Educational Outcome: The Case of } \\
\text { El Salvador's EDUCO Program }\end{array}$ & Yasuyuki Sawada & November 1999 \\
\hline $\begin{array}{l}\text { No. } 306 \text { Gender Wage Gap and Segregation in } \\
\text { Late Transition }\end{array}$ & Stepan Jurajda & May 2000 \\
\hline $\begin{array}{l}\text { No. } 305 \text { The Gender Pay Gap in the Transition } \\
\text { from Communism: Some Empirical Evidence }\end{array}$ & Andrew Newell and Barry Reilly & May 2000 \\
\hline
\end{tabular}

Working Papers are available at:

www.wdi.bus.umich.edu 


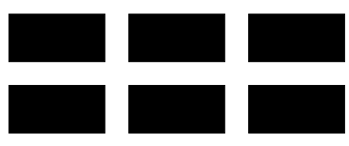

THE WILLIAM DAVIDSON INSTITUTE AT THE UNIVERSITY OF MICHIGAN BUSINESSSCHOOL

\begin{tabular}{|c|c|c|}
\hline $\begin{array}{l}\text { No. } 304 \text { Post-Unification Wage Growth in } \\
\text { East Germany }\end{array}$ & Jennifer Hunt & November 1998 \\
\hline $\begin{array}{l}\text { No. } 303 \text { How Does Privatization Affect } \\
\text { Workers? The Case of the Russian Mass } \\
\text { Privatization Program }\end{array}$ & Elizabeth Brainerd & May 2000 \\
\hline $\begin{array}{l}\text { No. } 302 \text { Liability for Past Environmental } \\
\text { Contamination and Privatization }\end{array}$ & Dietrich Earnhart & March 2000 \\
\hline No. 301 Varieties, Jobs and EU Enlargement & Tito Boeri and Joaquim Oliveira Martins & May 2000 \\
\hline No. 300 Employer Size Effects in Russia & Todd Idson & April 2000 \\
\hline $\begin{array}{l}\text { No. } 299 \text { Information Complements, } \\
\text { Substitutes, and Strategic Product Design }\end{array}$ & $\begin{array}{l}\text { Geoffrey G. Parker and Marshall W. Van } \\
\text { Alstyne }\end{array}$ & March 2000 \\
\hline $\begin{array}{l}\text { No. } 298 \text { Markets, Human Capital, and } \\
\text { Inequality: Evidence from Rural China }\end{array}$ & $\begin{array}{l}\text { Dwayne Benjamin, Loren Brandt, Paul } \\
\text { Glewwe, and Li Guo }\end{array}$ & May 2000 \\
\hline $\begin{array}{l}\text { No. } 297 \text { Corporate Governance in the Asian } \\
\text { Financial Crisis }\end{array}$ & $\begin{array}{l}\text { Simon Johnson, Peter Boone, Alasdair } \\
\text { Breach, and Eric Friedman }\end{array}$ & November 1999 \\
\hline $\begin{array}{l}\text { No. } 296 \text { Competition and Firm Performance: } \\
\text { Lessons from Russia }\end{array}$ & J. David Brown and John S. Earle & March 2000 \\
\hline $\begin{array}{l}\text { No. } 295 \text { Wage Determination in Russia: An } \\
\text { Econometric Investigation }\end{array}$ & Peter J. Luke and Mark E. Schaffer & March 2000 \\
\hline $\begin{array}{l}\text { No. 294: Can Banks Promote Enterprise } \\
\text { Restructuring?: Evidence From a Polish } \\
\text { Bank's Experience }\end{array}$ & John P. Bonin and Bozena Leven & March 2000 \\
\hline $\begin{array}{l}\text { No. 293: Why do Governments Sell Privatised } \\
\text { Companies Abroad? }\end{array}$ & $\begin{array}{l}\text { Bernardo Bortolotti, Marcella Fantini and } \\
\text { Carlo Scarpa }\end{array}$ & March 2000 \\
\hline $\begin{array}{l}\text { No. 292: Going Public in Poland: Case-by- } \\
\text { Case Privatizations, Mass Privatization and } \\
\text { Private Sector Initial Public Offerings }\end{array}$ & Wolfgang Aussenegg & December 1999 \\
\hline $\begin{array}{l}\text { No. 291: Institutional Technology and the } \\
\text { Chains of Trust: Capital Markets and } \\
\text { Privatization in Russia and the Czech } \\
\text { Republic }\end{array}$ & Bruce Kogut and Andrew Spicer & March 1999 \\
\hline $\begin{array}{l}\text { No. 290: Banking Crises and Bank Rescues: } \\
\text { The Effect of Reputation }\end{array}$ & Jenny Corbett and Janet Mitchell & January 2000 \\
\hline $\begin{array}{l}\text { No. 289: Do Active Labor Market Policies } \\
\text { Help Unemployed Workers to Find and Keep } \\
\text { Regular Jobs? }\end{array}$ & Jan C. van Ours & February 2000 \\
\hline $\begin{array}{l}\text { No. 288: Consumption Patterns of the New } \\
\text { Elite in Zimbabwe }\end{array}$ & Russell Belk & February 2000 \\
\hline $\begin{array}{l}\text { No. 287: Barter in Transition Economies: } \\
\text { Competing Explanations Confront Ukranian } \\
\text { Data }\end{array}$ & $\begin{array}{l}\text { Dalia Marin, Daniel Kaufmann and } \\
\text { Bogdan Gorochowskij }\end{array}$ & January 2000 \\
\hline $\begin{array}{l}\text { No. 286: The Quest for Pension Reform: } \\
\text { Poland's Security through Diversity }\end{array}$ & Marek Góra and Michael Rutkowski & January 2000 \\
\hline $\begin{array}{l}\text { No. 285: Disorganization and Financial } \\
\text { Collapse }\end{array}$ & Dalia Marin and Monika Schnitzer & October 1999 \\
\hline $\begin{array}{l}\text { No. 284: Coordinating Changes in M-form } \\
\text { and U-form Organizations }\end{array}$ & $\begin{array}{l}\text { Yingyi Qian, Gérard Roland and } \\
\text { Chenggang Xu }\end{array}$ & May 1999 \\
\hline $\begin{array}{l}\text { No. 283: Why Russian Workers Do Not } \\
\text { Move: Attachment of Workers Through In- } \\
\text { Kind Payments }\end{array}$ & Guido Friebel and Sergei Guriev & October 1999 \\
\hline No. 282: Lessons From Fiascos in Russian & Merritt B. Fox and Michael A. Heller & October 1999 \\
\hline
\end{tabular}

Working Papers are available at: www.wdi.bus.umich.edu 


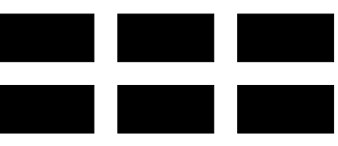

ThE WiLliam DAVIDSON InSTITUTE AT THE UNIVERSITY OF MICHIGAN BUSINESSSCHOOL

\begin{tabular}{|c|c|c|}
\hline Corporate Governance & & \\
\hline $\begin{array}{l}\text { No. 281: Income Distribution and Price } \\
\text { Controls: Targeting a Social Safety Net } \\
\text { During Economic Transition }\end{array}$ & Michael Alexeev and James Leitzel & March 1999 \\
\hline $\begin{array}{l}\text { No. 280: Starting Positions, Reform Speed, } \\
\text { and Economic Outcomes in Transitioning } \\
\text { Economies }\end{array}$ & William Hallagan and Zhang Jun & January 2000 \\
\hline No. 279: The Value of Prominent Directors & Yoshiro Miwa \& J. Mark Ramseyer & October 1999 \\
\hline No. 278: The System Paradigm & János Kornai & April 1998 \\
\hline $\begin{array}{l}\text { No. 277: The Developmental Consequences of } \\
\text { Foreign Direct Investment in the Transition } \\
\text { from Socialism to Capitalism: The } \\
\text { Performance of Foreign Owned Firms in } \\
\text { Hungary }\end{array}$ & Lawrence Peter King & September 1999 \\
\hline $\begin{array}{l}\text { No. 276: Stability and Disorder: An } \\
\text { Evolutionary Analysis of Russia's Virtual } \\
\text { Economy }\end{array}$ & Clifford Gaddy and Barry W. Ickes & November 1999 \\
\hline $\begin{array}{l}\text { No. 275: Limiting Government Predation } \\
\text { Through Anonymous Banking: A Theory with } \\
\text { Evidence from China. }\end{array}$ & $\begin{array}{l}\text { Chong-En Bai, David D. Li, Yingyi Qian } \\
\text { and Yijiang Wang }\end{array}$ & July 1999 \\
\hline No. 274: Transition with Labour Supply & Tito Boeri & December 1999 \\
\hline $\begin{array}{l}\text { No. 273: Sectoral Restructuring and Labor } \\
\text { Mobility: A Comparative Look at the Czech } \\
\text { Republic }\end{array}$ & Vit Sorm and Katherine Terrell & November 1999 \\
\hline $\begin{array}{l}\text { No. 272: Published in: Journal of Comparative } \\
\text { Economics "Returns to Human Capital Under } \\
\text { the Communist Wage Grid and During the } \\
\text { Transition to a Market Economy" Vol. 27, pp. } \\
\text { 33-60 1999. }\end{array}$ & $\begin{array}{l}\text { Daniel Munich, Jan Svejnar and Katherine } \\
\text { Terrell }\end{array}$ & October 1999 \\
\hline $\begin{array}{l}\text { No. 271: Barter in Russia: Liquidity Shortage } \\
\text { Versus Lack of Restructuring }\end{array}$ & Sophie Brana and Mathilde Maurel & June 1999 \\
\hline $\begin{array}{l}\text { No. 270: Tests for Efficient Financial } \\
\text { Intermediation with Application to China }\end{array}$ & Albert Park and Kaja Sehrt & March 1999 \\
\hline $\begin{array}{l}\text { No. 269a: Russian Privatization and Corporate } \\
\text { Governance: What Went Wrong? }\end{array}$ & $\begin{array}{l}\text { Bernard Black, Reinier Kraakman and } \\
\text { Anna Tarassova }\end{array}$ & May 2000 \\
\hline $\begin{array}{l}\text { No. 269: Russian Privatization and Corporate } \\
\text { Governance: What Went Wrong? }\end{array}$ & $\begin{array}{l}\text { Bernard Black, Reinier Kraakman and } \\
\text { Anna Tarassova }\end{array}$ & September 1999 \\
\hline $\begin{array}{l}\text { No. 268: Are Russians Really Ready for } \\
\text { Capitalism? }\end{array}$ & Susan Linz & September 1999 \\
\hline $\begin{array}{l}\text { No. 267: Do Stock Markets Promote } \\
\text { Economic Growth? }\end{array}$ & $\begin{array}{l}\text { Randall K. Filer, Jan Hanousek and Nauro } \\
\text { Campos }\end{array}$ & September 1999 \\
\hline $\begin{array}{l}\text { No. 266: Objectivity, Proximity and } \\
\text { Adaptability in Corporate Governance }\end{array}$ & Arnoud W.A Boot and Jonathan R. Macey & September 1999 \\
\hline $\begin{array}{l}\text { No. 265: When the Future is not What it Used } \\
\text { to Be: Lessons from the Western European } \\
\text { Experience to Forecasting Education and } \\
\text { Training in Transitional Economies }\end{array}$ & $\begin{array}{l}\text { Nauro F. Campos, Gerard Hughes, Stepan } \\
\text { Jurajda, and Daniel Munich }\end{array}$ & September 1999 \\
\hline $\begin{array}{l}\text { No. 264: The Institutional Foundation of } \\
\text { Foreign-Invested Enterprises (FIEs) in China }\end{array}$ & Yasheng Huang & September 1999 \\
\hline No. 263: The Changing Corporate Governance & Erik Berglof and Ernst-Ludwig von & June 1999 \\
\hline
\end{tabular}

Working Papers are available at: www.wdi.bus.umich.edu 


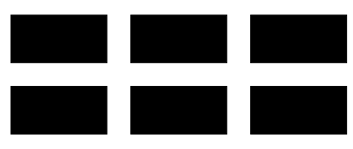

THE WILLIAM DAVIDSON INSTITUTE AT THE UNIVERSITY OF MICHIGAN BUSINESSSCHOOL

\begin{tabular}{|c|c|c|}
\hline $\begin{array}{l}\text { Paradigm: Implications for Transition and } \\
\text { Developing Countries }\end{array}$ & Thadden & \\
\hline No. 262: Law Enforcement and Transition & Gerard Roland and Thierry Verdier & May 1999 \\
\hline $\begin{array}{l}\text { No. 261: Soft Budget Constraints, Pecuniary } \\
\text { Externality, and the Dual Track System }\end{array}$ & Jiahua Che & June 2000 \\
\hline $\begin{array}{l}\text { No. 260: Missing Market in Labor Quality: } \\
\text { The Role of Quality Markets in Transition }\end{array}$ & Gary H. Jefferson & July 1999 \\
\hline $\begin{array}{l}\text { No. 259: Do Corporate Global Environmental } \\
\text { Standards in Emerging Markets Create or } \\
\text { Destroy Market Value }\end{array}$ & $\begin{array}{l}\text { Glen Dowell, Stuart Hart and Bernard } \\
\text { Yeung }\end{array}$ & June 1999 \\
\hline $\begin{array}{l}\text { No. 258: Public Training and Outflows from } \\
\text { Unemployment }\end{array}$ & Patrick A. Puhani & June 1999 \\
\hline $\begin{array}{l}\text { No. 257: Ownership Versus Environment: } \\
\text { Why are Public Sector Firms Inefficient? }\end{array}$ & Ann P. Bartel and Ann E. Harrison & June 1999 \\
\hline $\begin{array}{l}\text { No. 256: Taxation and Evasion in the Presence } \\
\text { of Exortion by Organized Crime }\end{array}$ & $\begin{array}{l}\text { Michael Alexeev, Eckhard Janeba and } \\
\text { Stefan Osborne }\end{array}$ & November 1999 \\
\hline $\begin{array}{l}\text { No. 255: Revisiting Hungary's Bankruptcy } \\
\text { Episode }\end{array}$ & John P. Bonin and Mark E. Schaffer & September 1999 \\
\hline $\begin{array}{l}\text { No. 254: FDI in Emerging Markets: A Home- } \\
\text { Country View }\end{array}$ & Marina v.N Whitman & June 1999 \\
\hline $\begin{array}{l}\text { No. 253: The Asian Financial Crisis: What } \\
\text { Happened, and What is to be Done }\end{array}$ & Jeffrey D. Sachs and Wing Thye Woo & January 1999 \\
\hline $\begin{array}{l}\text { No. 252: Organizational Law as Asset } \\
\text { Partitioning }\end{array}$ & Henry Hansmann and Reinier Kraakman & September 1999 \\
\hline $\begin{array}{l}\text { No. 251: Consumer Behavior Research in } \\
\text { Emerging Consumer Markets: the Case of the } \\
\text { Optimum Stimulation Level in South Africa }\end{array}$ & $\begin{array}{l}\text { Jan-Benedict E. M. Steenkamp and Steven } \\
\text { M. Burgess }\end{array}$ & September 1999 \\
\hline $\begin{array}{l}\text { No. 250: Property Rights Formation and the } \\
\text { Organization of Exchange and Production in } \\
\text { Rural China }\end{array}$ & $\begin{array}{l}\text { Matthew A. Turner, Loren Brandt, and } \\
\text { Scott Rozelle }\end{array}$ & July 1998 \\
\hline $\begin{array}{l}\text { No. 249: Impacts of the Indonesian Economic } \\
\text { Crisis: Price Changes and the Poor }\end{array}$ & $\begin{array}{l}\text { James Levinsohn, Steven Berry, and Jed } \\
\text { Friedman }\end{array}$ & June 1999 \\
\hline $\begin{array}{l}\text { No. 248: Internal Barriers in the Transition of } \\
\text { Enterprises from Central Plan to Market }\end{array}$ & Charalambos Vlachoutsicos & July 1999 \\
\hline $\begin{array}{l}\text { No. 247: Spillovers from Multinationals in } \\
\text { Developing Countries: the Mechanisms at } \\
\text { Work }\end{array}$ & Richard E. Caves & June 1999 \\
\hline $\begin{array}{l}\text { No. 246: Dynamism and Inertia on the } \\
\text { Russian Labour Market: A Model of } \\
\text { Segmentation }\end{array}$ & $\begin{array}{l}\text { Irena Grosfeld, Claudia Senik-Leygonie, } \\
\text { Thierry Verdier, Stanislav Kolenikov and } \\
\text { Elena Paltseva }\end{array}$ & May 1999 \\
\hline $\begin{array}{l}\text { No. 245: Lessons from Bank Privatization in } \\
\text { Central Europe }\end{array}$ & John Bonin and Paul Wachtel & May 1999 \\
\hline $\begin{array}{l}\text { No. 244: Nominal-Real Tradeoffs and the } \\
\text { Effects of Monetary Policy: the Romanian } \\
\text { Experience }\end{array}$ & Christian Popa & December 1998 \\
\hline $\begin{array}{l}\text { No. 243: Privatization, Political Risk and } \\
\text { Stock Market Development in Emerging } \\
\text { Economies }\end{array}$ & Enrico C. Perotti and Pieter van Oijen & March 1999 \\
\hline $\begin{array}{l}\text { No. 242: Investment Financing in Russian } \\
\text { Financial-Industrial Groups }\end{array}$ & Enrico C. Perotti and Stanislav Gelfer & October 1998 \\
\hline $\begin{array}{l}\text { No. 241: Can governments maintain hard } \\
\text { budget constraints? Bank lending and }\end{array}$ & $\begin{array}{l}\text { Octavian Carare, Constantijn Claessens, } \\
\text { Enrico C. Perotti }\end{array}$ & January 1999 \\
\hline
\end{tabular}

Working Papers are available at:

www.wdi.bus.umich.edu 


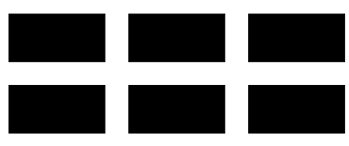

THE WILLIAM DAVIDSON INSTITUTE AT THE UNIVERSITY OF MICHIGAN BUSINESSSCHOOL

\begin{tabular}{|c|c|c|}
\hline financial isolation in Romania & & \\
\hline $\begin{array}{l}\text { No. 240: Democratic Institutions and } \\
\text { Economic Reform: the Polish Case }\end{array}$ & $\begin{array}{l}\text { John E. Jackson, Jacek Klich, and } \\
\text { Krystyna Poznanska }\end{array}$ & April 1998 \\
\hline $\begin{array}{l}\text { No. 239: A Longitudinal Study of IJV } \\
\text { Performance in Eastern Europe }\end{array}$ & Keith D. Brouthers and Gary Bamossy & June 1999 \\
\hline $\begin{array}{l}\text { No. 238: Published in: Journal of Business } \\
\text { Venturing, "Firm Creation and Economic } \\
\text { Transitions" Vol. 14, Iss. 5,6 Sep/Nov 1999, } \\
\text { pp. 427-450. }\end{array}$ & $\begin{array}{l}\text { John E. Jackson, Jacek Klich, Krystyna } \\
\text { Poznanska }\end{array}$ & July 1998 \\
\hline $\begin{array}{l}\text { No. 237: Analysis of Entrepreneurial Attitudes } \\
\text { in Poland }\end{array}$ & $\begin{array}{l}\text { John E. Jackson and Aleksander S. } \\
\text { Marcinkowski }\end{array}$ & March 1997 \\
\hline $\begin{array}{l}\text { No. 236: Investment and Finance in De Novo } \\
\text { Private Firms: Empirical Results from the } \\
\text { Czech Republic, Hungary, and Poland }\end{array}$ & $\begin{array}{l}\text { Andrzej Bratkowski, Irena Grosfeld, Jacek } \\
\text { Rostowski }\end{array}$ & April 1999 \\
\hline $\begin{array}{l}\text { No. 235: Does a Soft Macroeconomic } \\
\text { Environment Induce Restructuring on the } \\
\text { Microeconomic Level during the Transition } \\
\text { Period? Evidence from Investment Behavior } \\
\text { of Czech Enterprises }\end{array}$ & Lubomír Lízal & June 1999 \\
\hline $\begin{array}{l}\text { No. 234: Banking Reform in China: Gradually } \\
\text { Strengthening Pillar or Fragile Reed? }\end{array}$ & John Bonin & June 1999 \\
\hline $\begin{array}{l}\text { No. 233: Theories of Soft Budget Constraints } \\
\text { and the Analysis of Banking Crises }\end{array}$ & Janet Mitchell & March 1999 \\
\hline $\begin{array}{l}\text { No. 232: Unemployment Risk, Precautionary } \\
\text { Savings, and Moonlighting in Russia }\end{array}$ & $\begin{array}{l}\text { Alessandra Guariglia and Byung-Yeon } \\
\text { Kim }\end{array}$ & June 1999 \\
\hline $\begin{array}{l}\text { No. 231: Investing in Turbulent Times: The } \\
\text { Investment Behavior of Polish Firms in the } \\
\text { Transition }\end{array}$ & $\begin{array}{l}\text { Josef C. Brada, Arthur E. King, and Chia- } \\
\text { Ying Ma }\end{array}$ & April 1999 \\
\hline $\begin{array}{l}\text { No. 230: The End of Moderate Inflation in } \\
\text { Three Transition Economies? }\end{array}$ & Josef C. Brada and Ali M. Kutan & April 1999 \\
\hline $\begin{array}{l}\text { No. 229: Back to the Future: The Growth } \\
\text { Prospects of Transition Economies } \\
\text { Reconsidered }\end{array}$ & Nauro F. Campos & April 1999 \\
\hline $\begin{array}{l}\text { No. 228: The Enterprise Isolation Program in } \\
\text { Russia }\end{array}$ & Simeon Djankov & April 1999 \\
\hline $\begin{array}{l}\text { No. 227: Published in: Journal of Comparative } \\
\text { Economics, "Ownership Concentration and } \\
\text { Corporate Performance in the Czech } \\
\text { Republic" 27(3), September 1999, pp. 498- } \\
\text { 513. }\end{array}$ & Stijn Claessens and Simeon Djankov & April 1999 \\
\hline $\begin{array}{l}\text { No. 226: Unemployment Benefit Entitlement } \\
\text { and Training Effects in Poland during } \\
\text { Transition }\end{array}$ & Patrick A. Puhani & March 1999 \\
\hline $\begin{array}{l}\text { No. 225: Transition at Whirlpool-Tatramat: } \\
\text { Case Studies }\end{array}$ & Hans Brechbuhl and Sonia Ferencikova & March 1999 \\
\hline $\begin{array}{l}\text { No. 224: Measuring Progress in Transition } \\
\text { and Towards EU Accession: A Comparison } \\
\text { of Manufacturing Firms in Poland, Romania, } \\
\text { and Spain }\end{array}$ & $\begin{array}{l}\text { Wendy Carlin, Saul Estrin, and Mark } \\
\text { Schaffer }\end{array}$ & March 1999 \\
\hline $\begin{array}{l}\text { No. 223: Product Market Competition in } \\
\text { Transition Economies: Increasing Varieties } \\
\text { and Consumer Loyalty }\end{array}$ & Mitsutoshi M. Adachi & March 1999 \\
\hline
\end{tabular}

Working Papers are available at: www.wdi.bus.umich.edu 


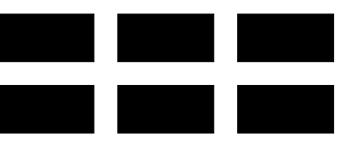

THE WILLIAM DAVIDSON INSTITUTE

AT THE UNIVERSITY OF MICHIGAN BUSINESSSCHOOL

\begin{tabular}{|c|c|c|}
\hline $\begin{array}{l}\text { No. 222: Opaque Markets and Rapid Growth: } \\
\text { the Superiority of Bank-Centered Financial } \\
\text { Systems for Developing Nations }\end{array}$ & Rodney Wallace & July 1999 \\
\hline $\begin{array}{l}\text { No. 221: Technology Spillovers through } \\
\text { Foreign Direct Investment }\end{array}$ & Yuko Kinoshita & January 1999 \\
\hline $\begin{array}{l}\text { No. 220: Managerial, Expertise and Team } \\
\text { Centered Forms of Organizing: A Cross- } \\
\text { Cultural Exploration of Independence in } \\
\text { Engineering Work }\end{array}$ & Leslie Perlow & January 1999 \\
\hline $\begin{array}{l}\text { No. 219: Household Structure and Labor } \\
\text { Demand in Agriculture: Testing for } \\
\text { Separability in Rural China }\end{array}$ & Audra J. Bowlus and Terry Sicular & January 1999 \\
\hline $\begin{array}{l}\text { No. 218: Competing Strategies of FDI and } \\
\text { Technology Transfer to China: American and } \\
\text { Japanese Firms }\end{array}$ & W. Mark Fruin and Penelope Prime & January 1999 \\
\hline $\begin{array}{l}\text { No. } 217 \text { Published in: Journal of Comparative } \\
\text { Economics, "Returns to Mobility in the } \\
\text { Transition to a Market Economy" Vol. 27, No. } \\
\text { 1, March 1999, pp. 4- }\end{array}$ & Tito Boeri and Christopher J. Flinn & January 1999 \\
\hline $\begin{array}{l}\text { No. } 216 \text { Published in: Journal of Comparative } \\
\text { Economics, "Labor Market Policies and } \\
\text { Unemployment in the Czech Republic." Vol. } \\
\text { 27, No. 1, March 1999, pp. 33-60. }\end{array}$ & Katherine Terrell and Vit Sorm & November 1998 \\
\hline $\begin{array}{l}\text { No. } 215 \text { Published in: Journal of Comparative } \\
\text { Economics, "Active Labor Market Policies in } \\
\text { Poland: Human Capital Enhancement, } \\
\text { Stigmatization or Benefit Churning?" Vol. 27, } \\
\text { No. 1, March 1999, pp. 61- }\end{array}$ & $\begin{array}{l}\text { Jochen Kluve, Hartmut Lehmann, and } \\
\text { Christoph M. Schmidt }\end{array}$ & December 1998 \\
\hline $\begin{array}{l}\text { No. } 214 \text { Published in: Journal of Comparative } \\
\text { Economics, "Does the Slovenian Public Work } \\
\text { Program Increase Participants' Chances to } \\
\text { Find a Job?" Vol. 27, No.1, March 1999, pp. } \\
\text { 113- }\end{array}$ & Milan Vodopivec & December 1998 \\
\hline $\begin{array}{l}\text { No. } 213 \text { Published in: Journal of Comparative } \\
\text { Economics, "Effects of Active Labor Market } \\
\text { Programs on the Transition Rate from } \\
\text { Unemployment into Regular Jobs in the } \\
\text { Slovak Republic." Vol. 27, No. 1, March } \\
\text { 1999, pp. 90- }\end{array}$ & Martina Lubyova and Jan C. van Ours & December 1998 \\
\hline $\begin{array}{l}\text { No. 212: The Marketing System in Bulgarian } \\
\text { Livestock Production - The Present State and } \\
\text { Evolutionary Processes During the Period of } \\
\text { Economic Transition }\end{array}$ & Yordan Staykov, Team Leader & October 1998 \\
\hline $\begin{array}{l}\text { No. 211: Bankruptcy Experience in Hungary } \\
\text { and the Czech Republic }\end{array}$ & Janet Mitchell & October 1998 \\
\hline $\begin{array}{l}\text { No 210: Values, Optimum Stimulation Levels } \\
\text { and Brand Loyalty: New Scales in New } \\
\text { Populations }\end{array}$ & Steven M. Burgess and Mari Harris & September 1998 \\
\hline $\begin{array}{l}\text { No. 209: Inherited Wealth, Corporate Control } \\
\text { and Economic Growth }\end{array}$ & $\begin{array}{l}\text { Randall K. Morck, David A. Stangeland, } \\
\text { and Bernard Yeung }\end{array}$ & September 1998 \\
\hline $\begin{array}{l}\text { No. 208: A Cultural Analysis of Homosocial } \\
\text { Reproduction and Contesting Claims to }\end{array}$ & Michael D. Kennedy & July 1998 \\
\hline
\end{tabular}

Working Papers are available at: www.wdi.bus.umich.edu 


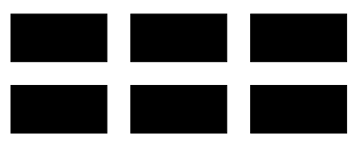

THE WILLIAM DAVIDSON INSTITUTE

AT THE UNIVERSITY OF MICHIGAN BUSINESSSCHOOL

\begin{tabular}{|c|c|c|}
\hline Competence in Transitional Firms & & \\
\hline $\begin{array}{l}\text { No. 207: From Survival to Success: The } \\
\text { Journey of Corporate Transformation at Haier. } \\
\text { Forthcoming in Teaching the Dinosaurs to } \\
\text { Dance: Organizational Change in Transition } \\
\text { Economies ed. Daniel Denison. }\end{array}$ & Arthur Yeung and Kenneth DeWoskin & July 1998 \\
\hline $\begin{array}{l}\text { No. 206: Why Do People Work If They Are } \\
\text { Not Paid? An Example from Eastern Europe. } \\
\text { Forthcoming in Teaching the Dinosaurs to } \\
\text { Dance: Organizational Change in Transition } \\
\text { Economies ed. Daniel Denison. }\end{array}$ & Irina L. Zinovieva & May 1998 \\
\hline $\begin{array}{l}\text { No. 205: Firm Ownership and Work } \\
\text { Motivation in Bulgaria and Hungary: An } \\
\text { Empirical Study of the Transition in the Mid- } \\
\text { 1990s. Forthcoming in Teaching the } \\
\text { Dinosaurs to Dance: Organizational Change in } \\
\text { Transition Economies ed. Daniel Denison. }\end{array}$ & $\begin{array}{l}\text { Robert A. Roe, Irina L. Zinovieva, } \\
\text { Elizabeth Dienes, and Laurens A. ten Horn }\end{array}$ & May 1998 \\
\hline $\begin{array}{l}\text { No. 204: Human Resource Management in the } \\
\text { Restructuring of Chinese Joint Ventures. } \\
\text { Forthcoming in Teaching the Dinosaurs to } \\
\text { Dance: Organizational Change in Transition } \\
\text { Economies ed. Daniel Denison. }\end{array}$ & Nandani Lynton & April 1998 \\
\hline $\begin{array}{l}\text { No. 203: Emergent Compensation Strategies } \\
\text { in Post-Socialist Poland: Understanding the } \\
\text { Cognitive Underpinnings of Management } \\
\text { Practices in a Transition Economy. } \\
\text { Forthcoming in Teaching the Dinosaurs to } \\
\text { Dance: Organizational Change in Transition } \\
\text { Economies ed. Daniel Denison. }\end{array}$ & Marc Weinstein & March 1998 \\
\hline $\begin{array}{l}\text { No. 202: Corporate Transformation and } \\
\text { Organizational Learning: The People's } \\
\text { Republic of China. Forthcoming in Teaching } \\
\text { the Dinosaurs to Dance: Organizational } \\
\text { Change in Transition Economies ed. Daniel } \\
\text { Denison. }\end{array}$ & Meinolf Dierkes and Zhang Xinhua & March 1998 \\
\hline $\begin{array}{l}\text { No. 201: Foreign Direct Investment as a } \\
\text { Factor of Change: The Case of Slovakia. } \\
\text { Forthcoming in Teaching the Dinosaurs to } \\
\text { Dance: Organizational Change in Transition } \\
\text { Economies ed. Daniel Denison. }\end{array}$ & Sonia Ferencikova & February 1998 \\
\hline $\begin{array}{l}\text { No. 200: Radical versus Incremental Change: } \\
\text { The Role of Capabilities, Competition, and } \\
\text { Leaders. Forthcoming in Teaching the } \\
\text { Dinosaurs to Dance: Organizational Change in } \\
\text { Transition Economies ed. Daniel Denison. }\end{array}$ & Karen L. Newman & February 1998 \\
\hline $\begin{array}{l}\text { No. 199: The Emergence of Market Practices } \\
\text { in China's Economic Transition: Price Setting } \\
\text { Practices in Shanghai's Industrial Firms. } \\
\text { Forthcoming in Teaching the Dinosaurs to } \\
\text { Dance: Organizational Change in Transition } \\
\text { Economies ed. Daniel Denison. }\end{array}$ & Douglas Guthrie & February 1998 \\
\hline No. 198: The Application of Change & Dr. János Fehér & January 1998 \\
\hline
\end{tabular}

Working Papers are available at: www.wdi.bus.umich.edu 


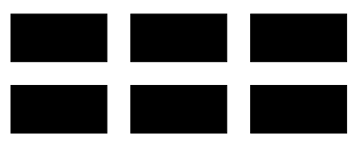

THE WILLIAM DAVIDSON INSTITUTE AT THE UNIVERSITY OF MICHIGAN BUSINESSSCHOOL

\begin{tabular}{|c|c|c|}
\hline $\begin{array}{l}\text { Management Methods at Business } \\
\text { Organizations Operating in Hungary: } \\
\text { Challenges in the Business and Cultural } \\
\text { Environment and First Practical Experiences. } \\
\text { Forthcoming in Teaching the Dinosaurs to } \\
\text { Dance: Organizational Change in Transition } \\
\text { Economies ed. Daniel Denison. }\end{array}$ & & \\
\hline $\begin{array}{l}\text { No. 197: Organizational Changes in Russian } \\
\text { Industrial Enterprises: Mutation of Decision- } \\
\text { Making Structures and Transformations of } \\
\text { Ownership. Forthcoming in Teaching the } \\
\text { Dinosaurs to Dance: Organizational Change in } \\
\text { Transition Economies ed. Daniel Denison. }\end{array}$ & Igor B. Gurkov & January 1998 \\
\hline $\begin{array}{l}\text { No. 196: Understanding and Managing } \\
\text { Challenges to the Romanian Companies } \\
\text { during Transition. Forthcoming in Teaching } \\
\text { the Dinosaurs to Dance: Organizational } \\
\text { Change in Transition Economies ed. Daniel } \\
\text { Denison. }\end{array}$ & Dan Candea and Rodica M. Candea & January 1998 \\
\hline $\begin{array}{l}\text { No. 195: Insider Lending and Economic } \\
\text { Transition: The Structure, Function, and } \\
\text { Performance Impact of Finance Companies in } \\
\text { Chinese Business Groups. Forthcoming in } \\
\text { Teaching the Dinosaurs to Dance: } \\
\text { Organizational Change in Transition } \\
\text { Economies ed. Daniel Denison. }\end{array}$ & Lisa A. Keister & December 1997 \\
\hline $\begin{array}{l}\text { No. 194: Japanese Investment in Transitional } \\
\text { Economies: Characteristics and Performance. } \\
\text { Forthcoming in Teaching the Dinosaurs to } \\
\text { Dance: Organizational Change in Transition } \\
\text { Economies ed. Daniel Denison. }\end{array}$ & Paul W. Beamish and Andrew Delios & November 1997 \\
\hline $\begin{array}{l}\text { No. 193: Building Successful Companies in } \\
\text { Transition Economies. Forthcoming in } \\
\text { Teaching the Dinosaurs to Dance: } \\
\text { Organizational Change in Transition } \\
\text { Economies ed. Daniel Denison. }\end{array}$ & Dr. Ivan Perlaki & January 1998 \\
\hline $\begin{array}{l}\text { No. 192: Russian Communitariansim: An } \\
\text { Invisible Fist in the Transformation Process of } \\
\text { Russia. Forthcoming in Teaching the } \\
\text { Dinosaurs to Dance: Organizational Change in } \\
\text { Transition Economies ed. Daniel Denison. }\end{array}$ & Charalambos Vlachoutsicos & July 1998 \\
\hline No. 191: Teaching the Dinosaurs to Dance & Michal Cakrt & September 1997 \\
\hline $\begin{array}{l}\text { No. 190: Strategic Restructuring: Making } \\
\text { Capitalism in Post-Communist Eastern } \\
\text { Europe. Forthcoming in Teaching the } \\
\text { Dinosaurs to Dance: Organizational Change in } \\
\text { Transition Economies ed. Daniel Denison. }\end{array}$ & Lawrence P. King & September 1997 \\
\hline $\begin{array}{l}\text { No. 189: Published in: Regional Science and } \\
\text { Urban Economics, "Russia's Internal Border", } \\
29 \text { (5), September } 1999 \text {. }\end{array}$ & Daniel Berkowitz and David N. DeJong & July 1998 \\
\hline $\begin{array}{l}\text { No. 187: Corporate Structure and Performance } \\
\text { in Hungary }\end{array}$ & László Halpern and Gábor Kórsöi & July 1998 \\
\hline
\end{tabular}

Working Papers are available at: www.wdi.bus.umich.edu 


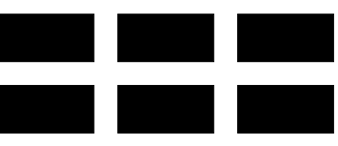

THE WILLIAM DAVIDSON INSTITUTE AT THE UNIVERSITY OF MICHIGAN BUSINESSSCHOOL

\begin{tabular}{|c|c|c|}
\hline $\begin{array}{l}\text { No. 186: Performance of Czech Companies by } \\
\text { Ownership Structure }\end{array}$ & Andrew Weiss and Georgiy Nikitin & June 1998 \\
\hline $\begin{array}{l}\text { No. 185: Firm Performance in Bulgaria and } \\
\text { Estonia: The effects of competitive pressure, } \\
\text { financial pressure and disorganisation }\end{array}$ & Jozef Konings & July 1998 \\
\hline $\begin{array}{l}\text { No. 184: Investment and Wages during the } \\
\text { Transition: Evidence from Slovene Firms }\end{array}$ & Janez Prasnikar and Jan Svejnar & July 1998 \\
\hline $\begin{array}{l}\text { No. 183: Investment Portfolio under Soft } \\
\text { Budget: Implications for Growth, Volatility } \\
\text { and Savings }\end{array}$ & Chongen Bai and Yijiang Wang & July 1998 \\
\hline $\begin{array}{l}\text { No. 181: Delegation and Delay in Bank } \\
\text { Privatization }\end{array}$ & Loránd Ambrus-Lakatos and Ulrich Hege & July 1998 \\
\hline $\begin{array}{l}\text { No. 180: Financing Mechanisms and R\&D } \\
\text { Investment }\end{array}$ & Haizhou Huang and Chenggang Xu & July 1998 \\
\hline $\begin{array}{l}\text { No. 179: Organizational Culture and } \\
\text { Effectiveness: The Case of Foreign Firms in } \\
\text { Russia }\end{array}$ & Carl F. Fey and Daniel R. Denison & January 1999 \\
\hline $\begin{array}{l}\text { No. 178: Output and Unemployment } \\
\text { Dynamics in Transition }\end{array}$ & Vivek H. Dehejia and Douglas W. Dwyer & January 1998 \\
\hline $\begin{array}{l}\text { No. 177: Published in: Economics of } \\
\text { Transition,, "Bureaucracies in the Russian } \\
\text { Voucher Privatization" Vol. 8, No. 1, 2000, } \\
\text { pp. 37-57. }\end{array}$ & Guido Friebel & June 1998 \\
\hline $\begin{array}{l}\text { No. 176: Chronic Moderate Inflation in } \\
\text { Transition: The Tale of Hungary }\end{array}$ & János Vincze & June 1998 \\
\hline $\begin{array}{l}\text { No. 175: Privatisation and Market Structure in } \\
\text { a Transition Economy }\end{array}$ & John Bennett and James Maw & June 1998 \\
\hline $\begin{array}{l}\text { No. 174: Ownership and Managerial } \\
\text { Competition: Employee, Customer, or Outside } \\
\text { Ownership }\end{array}$ & Patrick Bolton and Chenggang $\mathrm{Xu}$ & June 1998 \\
\hline $\begin{array}{l}\text { No. 173: Intragovernment Procurement of } \\
\text { Local Public Good: A Theory of } \\
\text { Decentralization in Nondemocratic } \\
\text { Government }\end{array}$ & Chong-en Bai, Yu Pan and Yijiang Wang & June 1998 \\
\hline $\begin{array}{l}\text { No. 172: Political Instability and Growth in } \\
\text { Proprietary Economies }\end{array}$ & Jody Overland and Michael Spagat & August 1998 \\
\hline $\begin{array}{l}\text { No. 171: Published in Post-Communist } \\
\text { Economies, "Framework Issues in the } \\
\text { Privatization Strategies of the Czech Republic, } \\
\text { Hungary, and Poland" Vol. 11, no. 1 March } \\
1999 .\end{array}$ & Morris Bornstein & June 1998 \\
\hline $\begin{array}{l}\text { No. 170: Published in: European Journal of } \\
\text { Political Economy "Privatization, Ownership } \\
\text { Structure and Transparency: How to Measure } \\
\text { a Real Involvement of the State" 15(4), } \\
\text { November 1999, pp. 605-18. }\end{array}$ & Frantisek Turnovec & May 1998 \\
\hline $\begin{array}{l}\text { No. } 169 \text { Published in: American Economic } \\
\text { Review, "Unemployment and the Social } \\
\text { Safety Net during Transitions to a Market } \\
\text { Economy: Evidence from Czech and Slovak } \\
\text { Men." Vol. 88, No. 5, Dec. 1998, pp. 1117- } \\
1142 \text {. }\end{array}$ & $\begin{array}{l}\text { John C. Ham, Jan Svejnar, and Katherine } \\
\text { Terrell }\end{array}$ & December 1998 \\
\hline
\end{tabular}

Working Papers are available at: www.wdi.bus.umich.edu 


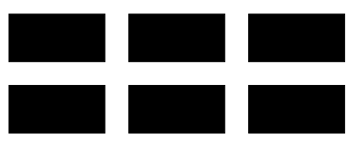

THE WILLIAM DAVIDSON INSTITUTE AT THE UNIVERSITY OF MICHIGAN BUSINESSSCHOOL

\begin{tabular}{|c|c|c|}
\hline $\begin{array}{l}\text { No. 167: Voucher Privatization with } \\
\text { Investment Funds: An Institutional Analysis }\end{array}$ & David Ellerman & March 1998 \\
\hline $\begin{array}{l}\text { No. 166: Published in: Marketing Issues in } \\
\text { Transitional Economies, "Value Priorities and } \\
\text { Consumer Behavior in a Transitional } \\
\text { Economy: The Case of South Africa" ed. } \\
\text { Rajeev Batra. }\end{array}$ & $\begin{array}{l}\text { Steven M. Burgess and Jan-Benedict E.M. } \\
\text { Steenkamp }\end{array}$ & August 1998 \\
\hline $\begin{array}{l}\text { No. 164: Finance and Investment in } \\
\text { Transition: Czech Enterprises, 1993-1994 }\end{array}$ & Ronald Anderson and Chantal Kegels & September 1997 \\
\hline $\begin{array}{l}\text { No. 163: European Union Trade and } \\
\text { Investment Flows U-Shaping Industrial } \\
\text { Output in Central and Eastern Europe: Theory } \\
\text { and Evidence }\end{array}$ & Alexander Repkine and Patrick P. Walsh & April 1998 \\
\hline $\begin{array}{l}\text { No. 162: Skill Acquisition and Private Firm } \\
\text { Creation in Transition Economies }\end{array}$ & Zuzana Brixiova and Wenli Li & October 1999 \\
\hline No. 161: Corruption in Transition & Susanto Basu and David D. Li & May 1998 \\
\hline $\begin{array}{l}\text { No. 160a: Tenures that Shook the World: } \\
\text { Worker Turnover in Russia, Poland and } \\
\text { Britain }\end{array}$ & $\begin{array}{l}\text { Hartmut Lehmann and Jonathan } \\
\text { Wadsworth }\end{array}$ & November 1999 \\
\hline $\begin{array}{l}\text { No. 160: Tenures that Shook the World: } \\
\text { Worker Turnover in the Russian Federation } \\
\text { and Poland }\end{array}$ & $\begin{array}{l}\text { Hartmut Lehmann and Jonathan } \\
\text { Wadsworth }\end{array}$ & June 1998 \\
\hline $\begin{array}{l}\text { No. 159: Does Market Structure Matter? New } \\
\text { Evidence from Russia }\end{array}$ & Annette N. Brown and J. David Brown & June 1998 \\
\hline $\begin{array}{l}\text { No. 158: Structural Adjustment and Regional } \\
\text { Long Term Unemployment in Poland }\end{array}$ & Hartmut Lehmann and Patrick P. Walsh & June 1997 \\
\hline $\begin{array}{l}\text { No. 157: Baby Boom or Bust? Changing } \\
\text { Fertility in Post-Communist Czech Republic } \\
\text { and Slovakia }\end{array}$ & Robert S. Chase & April 1998 \\
\hline $\begin{array}{l}\text { No. } 156 \text { Published in: Leadership and } \\
\text { Organization Development Journal, "Leading } \\
\text { Radical Change in Transition Economies." } \\
\text { Vol. 19, No. 6, 1998, pp. 309-324. }\end{array}$ & Karen L. Newman & June 1998 \\
\hline $\begin{array}{l}\text { No. } 155 \text { Published in: Oxford Review of } \\
\text { Economic Policy, "From Theory into } \\
\text { Practice? Restructuring and Dynamism in } \\
\text { Transition Economies." Vol. 13, No. 2, } \\
\text { Summer 1997, pp. 77-105. }\end{array}$ & Wendy Carlin and Michael Landesmann & June 1997 \\
\hline $\begin{array}{l}\text { No. 154: The Model and the Reality: } \\
\text { Assessment of Vietnamese SOE Reform- } \\
\text { Implementation at the Firm Level }\end{array}$ & $\begin{array}{l}\text { Edmund Malesky, Vu Thanh Hung, Vu } \\
\text { Thi Dieu Anh, and Nancy K. Napier }\end{array}$ & July 1998 \\
\hline $\begin{array}{l}\text { No. } 153 \text { Published in: Journal of Comparative } \\
\text { Economics, "Causes of the Soft Budget } \\
\text { Constraint: Evidence on Three Explanations." } \\
\text { Vol. 26, No. 1, March 1998, pp. 104-116. }\end{array}$ & David D. Li and Minsong Liang & March 1998 \\
\hline $\begin{array}{l}\text { No. } 152 \text { Published in: Comparative Economic } \\
\text { Studies, "Enterprise Restructuring in Russia's } \\
\text { Transition Economy: Formal and Informal } \\
\text { Mechanisms." Vol. 40, No. 2, Summer 1998, } \\
\text { pp. 5-52. }\end{array}$ & Susan J. Linz and Gary Krueger & April 1998 \\
\hline $\begin{array}{l}\text { No. 151: Labor Productivity in Transition: A } \\
\text { Regional Analysis of Russian Industry }\end{array}$ & Susan J. Linz & May 1998 \\
\hline
\end{tabular}

Working Papers are available at: www.wdi.bus.umich.edu 


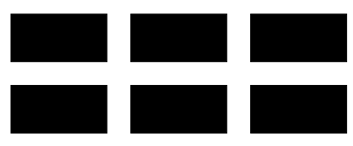

THE WILLIAM DAVIDSON INSTITUTE

AT THE UNIVERSITY OF MICHIGAN BUSINESSSCHOOL

\begin{tabular}{|c|c|c|}
\hline $\begin{array}{l}\text { No. 150: Tax Avoidance and the Allocation of } \\
\text { Credit. Forthcoming in Financial Systems in } \\
\text { Transition: The Design of Financial Systems } \\
\text { in Central Europe eds. Anna Meyendorff and } \\
\text { Anjan Thakor. }\end{array}$ & Anna Meyendorff & June 1998 \\
\hline $\begin{array}{l}\text { No. 149: Commitment, Versatility and } \\
\text { Balance: Determinants of Work Time } \\
\text { Standards and Norms in a Multi-Country } \\
\text { Study of Software Engineers }\end{array}$ & Leslie Perlow and Ron Fortgang & April 1998 \\
\hline $\begin{array}{l}\text { No. 148: Changes in Poland's Transfer } \\
\text { Payments in the 1990s: the Fate of Pensioners }\end{array}$ & Bozena Leven & June 1998 \\
\hline $\begin{array}{l}\text { No. 147: Environmental Protection and } \\
\text { Economic Development: The Case of the } \\
\text { Huaihe River Basin Cleanup Plan }\end{array}$ & $\begin{array}{l}\text { Robert Letovsky, Reze Ramazani, and } \\
\text { Debra Murphy }\end{array}$ & June 1998 \\
\hline $\begin{array}{l}\text { No. 146: Chief Executive Compensation } \\
\text { During Early Transition: Further Evidence } \\
\text { from Bulgaria }\end{array}$ & $\begin{array}{l}\text { Derek C. Jones, Takao Kato, and Jeffrey } \\
\text { Miller }\end{array}$ & June 1998 \\
\hline $\begin{array}{l}\text { No. } 145 \text { Published in: Economics of } \\
\text { Transition, "Women's Unemployment During } \\
\text { the Transition: Evidence from Czech and } \\
\text { Slovak Micro Data," Vol. 7, No. 1, May 1999, } \\
\text { pp. 47-78. }\end{array}$ & $\begin{array}{l}\text { John Ham, Jan Svejnar, and Katherine } \\
\text { Terrell }\end{array}$ & May 1998 \\
\hline No. 144: Investment and Wages in Slovenia & Janez Prasnikar & May 1998 \\
\hline $\begin{array}{l}\text { No. } 143 \text { Published in: Review of Financial } \\
\text { Studies, "Optimal Bankruptcy Laws Across } \\
\text { Different Economic Systems," 12(2), Summer } \\
\text { 1999, pgs. 347-77. }\end{array}$ & Elazar Berkovitch and Ronen Israel & March 1998 \\
\hline $\begin{array}{l}\text { No. 142: Industrial Policy and Poverty in } \\
\text { Transition Economies: Two Steps Forward or } \\
\text { One Step Back? }\end{array}$ & Susan J. Linz & March 1998 \\
\hline $\begin{array}{l}\text { No. 141: Collective Ownership and } \\
\text { Privatization of China's Village Enterprises }\end{array}$ & Suwen Pan and Albert Park & April 1998 \\
\hline $\begin{array}{l}\text { No. 140: A Comparative Look at Labor } \\
\text { Mobility in the Czech Republic: Where have } \\
\text { all the Workers Gone? }\end{array}$ & Vit Sorm and Katherine Terrell & April 1999 \\
\hline $\begin{array}{l}\text { No. 139: The Failure of the Government-Led } \\
\text { Program of Corporate Reorganization in } \\
\text { Romania }\end{array}$ & Simeon Djankov and Kosali Ilayperuma & September 1997 \\
\hline $\begin{array}{l}\text { No. 138: Ownership and Employment in } \\
\text { Russian Industry: 1992-1995 }\end{array}$ & Susan J. Linz & March 1998 \\
\hline $\begin{array}{l}\text { No. } 137 \text { Published in: Journal of Political } \\
\text { Economy, "Reform Without Losers: An } \\
\text { Interpretation of China's Dual-Track } \\
\text { Approach to Transition," Feb. 2000; Vol. 108, } \\
\text { Iss.1; pg. } 120\end{array}$ & $\begin{array}{l}\text { Lawrence J. Lau, Yingyi Qian, and Gerard } \\
\text { Roland }\end{array}$ & November 1997 \\
\hline $\begin{array}{l}\text { No. } 136 \text { Published in: European Economic } \\
\text { Review, "The Political Economy of Mass } \\
\text { Privatization and the Risk of Expropriation," } \\
\text { 44(2), February 2000, pgs. } 393-421\end{array}$ & Klaus M. Schmidt & March 1998 \\
\hline $\begin{array}{l}\text { No. 135: Radical Organizational Change: The } \\
\text { Role of Starting Conditions, Competition, and } \\
\text { Leaders }\end{array}$ & Karen L. Newman & January 1998 \\
\hline
\end{tabular}

Working Papers are available at: www.wdi.bus.umich.edu 


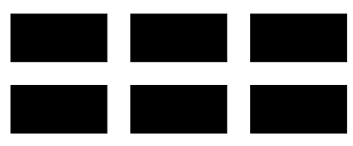

THE WILLIAM DAVIDSON INSTITUTE AT THE UNIVERSITY OF MICHIGAN BUSINESSSCHOOL

\begin{tabular}{|c|c|c|}
\hline $\begin{array}{l}\text { No. 134: To Restructure or Not to Restructure: } \\
\text { Informal Activities and Enterprise Behavior in } \\
\text { Transition } \\
\text { No. 133: Management 101: Behavior of Firms } \\
\text { in Transition Economies }\end{array}$ & $\begin{array}{l}\text { Clifford Gaddy and Barry W. Ickes } \\
\text { Josef C. Brada }\end{array}$ & $\begin{array}{l}\text { May } 1998 \\
\text { March } 1998\end{array}$ \\
\hline $\begin{array}{l}\text { No. } 132 \text { Published in: Quarterly Journal of } \\
\text { Economics, "Interfirm Relationships and } \\
\text { Informal Credit in Vietnam," 114(4), Nov. } \\
\text { 1999, pgs. 1285-1320 }\end{array}$ & John McMillan and Christopher Woodruff & February 1998 \\
\hline $\begin{array}{l}\text { No. } 131 \text { Published in: Comparative Economic } \\
\text { Studies, "Will Restructuring Hungarian } \\
\text { Companies Innovate? An Investigation Based } \\
\text { on Joseph Berliner's Analysis of Innovation in } \\
\text { Soviet Industry." Vol. 40, No. 2, Summer } \\
\text { 1998, pp. 53-74. }\end{array}$ & John B. Bonin and Istvan Abel & March 1998 \\
\hline $\begin{array}{l}\text { No. 130: Published in The American } \\
\text { Economic Review, "Changing Incentives of } \\
\text { the Chinese Bureaucracy." May, } 1998 \text {. }\end{array}$ & David D. Li & January 1998 \\
\hline $\begin{array}{l}\text { No. 129: Restructuring Investment in } \\
\text { Transition: A Model of the Enterprise } \\
\text { Decision }\end{array}$ & Richard E. Ericson & January 1998 \\
\hline $\begin{array}{l}\text { No. } 128 \text { Published in: Comparative Economic } \\
\text { Studies, “Job Rights in Russian Firms: } \\
\text { Endangered or Extinct Institutions?” Vol. 40, } \\
\text { No. 4, Winter 1998, pp. 1-32. }\end{array}$ & Susan J. Linz & January 1998 \\
\hline $\begin{array}{l}\text { No. 127: Accounting for Growth in Post- } \\
\text { Soviet Russia }\end{array}$ & Daniel Berkowitz and David N. DeJong & January 1998 \\
\hline $\begin{array}{l}\text { No. } 126 \text { Published in: Economics of } \\
\text { Transition, "From Federalism, Chinese Style, } \\
\text { to Privatization Chinese Style," 7(1), 1999, } \\
\text { pgs. 103-31 }\end{array}$ & $\begin{array}{l}\text { Yuanzheng Cao, Yingyi Qian, and Barry } \\
\text { R. Weingast }\end{array}$ & December 1997 \\
\hline $\begin{array}{l}\text { No. 125: Market Discipline in Conglomerate } \\
\text { Banks: Is an Internal Allocation of Cost of } \\
\text { Capital Necessary as Incentive Device? } \\
\text { Forthcoming in Financial Systems in } \\
\text { Transition: The Design of Financial Systems } \\
\text { in Central Europe eds. Anna Meyendorff and } \\
\text { Anjan Thakor. }\end{array}$ & Arnoud W. A. Boot and Anjolein Schmeits & November 1997 \\
\hline $\begin{array}{l}\text { No. 124: Financial Discipline in the Enterprise } \\
\text { Sector in Transition Countries: How Does } \\
\text { China Compare? }\end{array}$ & Shumei Gao and Mark E. Schaffer & February 1998 \\
\hline $\begin{array}{l}\text { No. 123: Considerations of an Emerging } \\
\text { Marketplace: Managers' Perceptions in the } \\
\text { Southern African Economic Community }\end{array}$ & Brent Chrite and David Hudson & February 1998 \\
\hline $\begin{array}{l}\text { No. 122: A Model of the Informal Economy in } \\
\text { Transition Economies }\end{array}$ & $\begin{array}{l}\text { Simon Commander and Andrei } \\
\text { Tolstopiatenko }\end{array}$ & November 1997 \\
\hline $\begin{array}{l}\text { No. 121: Local Labour Market Dynamics in } \\
\text { the Czech and Slovak Republics }\end{array}$ & Peter Huber and Andreas Worgotter & November 1997 \\
\hline $\begin{array}{l}\text { No. 119: Institutional Upheaval and Company } \\
\text { Transformation in Emerging Market } \\
\text { Economies }\end{array}$ & Karen L. Newman & March 1998 \\
\hline No. 118: Industrial Decline and Labor & John S. Earle & October 1997 \\
\hline
\end{tabular}

Working Papers are available at: www.wdi.bus.umich.edu 


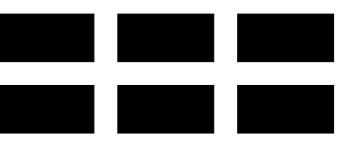

THE WILLIAM DAVIDSON INSTITUTE AT THE UNIVERSITY OF MICHIGAN BUSINESSSCHOOL

\begin{tabular}{|c|c|c|}
\hline Reallocation in Romania & & \\
\hline $\begin{array}{l}\text { No. 117: Notes for an Essay on the Soft } \\
\text { Budget Constraint }\end{array}$ & Lorand Ambrus-Lakatos & January 1997 \\
\hline $\begin{array}{l}\text { No. 116: Labor Demand During Transition in } \\
\text { Hungary }\end{array}$ & Gabor Korosi & October 1997 \\
\hline $\begin{array}{l}\text { No. 115: Enterprise Performance and } \\
\text { Managers' Profiles }\end{array}$ & Simeon Djankov and Stijn Claessens & December 1997 \\
\hline $\begin{array}{l}\text { No. 114b Employment and Wages in } \\
\text { Enterprises under Communism and in } \\
\text { Transition: Evidence From Central Europe and } \\
\text { Russia }\end{array}$ & Swati Basu, Saul Estrin, and Jan Svejnar & April 2000 \\
\hline $\begin{array}{l}\text { No. 114: Employment and Wage Behavior of } \\
\text { Enterprises in Transitional Economies }\end{array}$ & Swati Basu, Saul Estrin, and Jan Svejnar & October 1997 \\
\hline $\begin{array}{l}\text { No. 113: Preliminary Evidence on Active } \\
\text { Labor Programs' Impact in Hungary and } \\
\text { Poland }\end{array}$ & Christopher J. O’Leary & October 1997 \\
\hline $\begin{array}{l}\text { No. 111: Unemployment Benefits and } \\
\text { Incentives in Hungary: New Evidence }\end{array}$ & Joachim Wolff & October 1997 \\
\hline $\begin{array}{l}\text { No. 110: Published in: Empirical Economics, } \\
\text { "Long-Term Unemployment, Unemployment } \\
\text { Benefits and Social Assistance: The Polish } \\
\text { Experience" Empirical-Economics; 23(1-2), } \\
\text { 1998, pages 55-85. }\end{array}$ & Marek Gora and Christoph M. Schmidt & April 1997 \\
\hline $\begin{array}{l}\text { No. } 109 \text { Published in: Industrial and Labor } \\
\text { Relations Review, "Markets for Communist } \\
\text { Human Capital: Returns to Education and } \\
\text { Experience in Post-Communist Czech } \\
\text { Republic and Slovakia." Vol. 51, No. 3, April } \\
\text { 1998, pp. 401-423. }\end{array}$ & Robert S. Chase & October 1997 \\
\hline $\begin{array}{l}\text { No. 107: The Worker-Firm Matching in the } \\
\text { Transition: (Why) Are the Czechs More } \\
\text { Successful Than Others? }\end{array}$ & $\begin{array}{l}\text { Daniel Münich, Jan Svejnar, and Katherine } \\
\text { Terrell }\end{array}$ & October 1997 \\
\hline $\begin{array}{l}\text { No. } 106 \text { Published in: Journal of Comparative } \\
\text { Economics, "Job Creation, Job Destruction } \\
\text { and Growth of Newly Established, Privatized } \\
\text { and State-Owned Enterprises in Transition } \\
\text { Economies: Survey Evidence from Bulgaria, } \\
\text { Hungary, and Romania," Vol. 26, No.3, } \\
\text { September 1998, pp. 429-445. }\end{array}$ & Valentijn Bilsen and Jozef Konings & September 1998 \\
\hline $\begin{array}{l}\text { No. 105: Getting Behind the East-West } \\
\text { [German] Wage Differential: Theory and } \\
\text { Evidence }\end{array}$ & Michael Burda and Christoph Schmidt & May 1997 \\
\hline $\begin{array}{l}\text { No. 104: The Birth of the "Wage Curve" in } \\
\text { Hungary, 1989-95 }\end{array}$ & Gabor Kertesi and Janos Kollo & October 1997 \\
\hline $\begin{array}{l}\text { No. 103: Published in: Journal of Comparative } \\
\text { Economics, "Grime and Punishment: Job } \\
\text { Insecurity and Wage Arrears in the Russian } \\
\text { Federation" 27, 595-617 (1999). }\end{array}$ & $\begin{array}{l}\text { Hartmut Lehmann, Jonathan Wadsworth, } \\
\text { and Alessandro Acquisti }\end{array}$ & October 1997 \\
\hline No. 102: Social Networks in Transition & $\begin{array}{l}\text { Lorena Barberia, Simon Johnson, and } \\
\text { Daniel Kaufmann }\end{array}$ & October 1997 \\
\hline $\begin{array}{l}\text { No. 101: Depreciation and Russian Corporate } \\
\text { Finance: A Pragmatic Approach to Surviving }\end{array}$ & Susan J. Linz & November 1997 \\
\hline
\end{tabular}

Working Papers are available at:

www.wdi.bus.umich.edu 


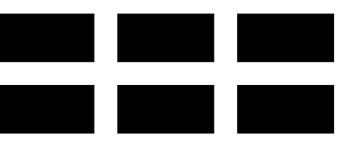

THE WILLIAM DAVIDSON INSTITUTE AT THE UNIVERSITY OF MICHIGAN BUSINESSSCHOOL

\begin{tabular}{|c|c|c|}
\hline the Transition & & \\
\hline No. 100: Romanian Financial System Reform & Anna Meyendorff and Anjan V. Thakor & November 1997 \\
\hline $\begin{array}{l}\text { No. 99: Proceedings of the Conference on } \\
\text { Strategic Alliances in Transitional Economies, } \\
\text { held May 20, } 1997 \text { at the Davidson Institute }\end{array}$ & Edited by Cynthia Koch & May 1997 \\
\hline $\begin{array}{l}\text { No. 98: Institutions, Strain and the } \\
\text { Underground Economy }\end{array}$ & Daniel Daianu and Lucian Albu & November 1997 \\
\hline $\begin{array}{l}\text { No. 97: Structure and Strain in Explaining } \\
\text { Inter-Enterprise Arrears }\end{array}$ & Daniel Daianu & November 1997 \\
\hline $\begin{array}{l}\text { No. 96: Resource Misallocation and Strain: } \\
\text { Explaining Shocks in Post-Command } \\
\text { Economies }\end{array}$ & Daniel Daianu & November 1997 \\
\hline $\begin{array}{l}\text { No. 95: Published in: Finance-a-Uver, "Czech } \\
\text { Money Market: Emerging Links Among } \\
\text { Interest Rates.” 48(2) } 1998 \text { pp. 99-109. }\end{array}$ & Jan Hanousek and Evzen Kocenda & November 1997 \\
\hline $\begin{array}{l}\text { No. 94: Pre-Reform Industry and the } \\
\text { State Monopsony in China }\end{array}$ & Xiao-Yuan Dong and Louis Putterman & October 1997 \\
\hline $\begin{array}{l}\text { No. 93: China's State-Owned Enterprises } \\
\text { In the First Reform Decade: } \\
\text { An Analysis of a Declining Monopsony }\end{array}$ & Xiao-Yuan Dong and Louis Putterman & October 1997 \\
\hline $\begin{array}{l}\text { No. 92: Expatriate Management in the Czech } \\
\text { Republic }\end{array}$ & Richard B. Peterson & September 1997 \\
\hline $\begin{array}{l}\text { No. 91: China and the Idea of Economic } \\
\text { Reform }\end{array}$ & Thomas G. Rawski & April 1997 \\
\hline $\begin{array}{l}\text { No. } 90 \text { Published in: China Economic Review, } \\
\text { "China's State Enterprise Reform: An } \\
\text { Overseas Perspective." Vol. 8, Spring 1997, } \\
\text { pp. 89-98. }\end{array}$ & Thomas G. Rawski & July 1997 \\
\hline $\begin{array}{l}\text { No. 89: The Economic Determinants of } \\
\text { Internal Migration Flows in Russia During } \\
\text { Transition }\end{array}$ & Annette N. Brown & July 1997 \\
\hline $\begin{array}{l}\text { No. 88: Gender Wage Gaps in China's Labor } \\
\text { Market: Size, Structure, Trends }\end{array}$ & $\begin{array}{l}\text { Margaret Maurer-Fazio, Thomas G. } \\
\text { Rawski, and Wei Zhang }\end{array}$ & July 1997 \\
\hline $\begin{array}{l}\text { No. 87: Privatisation in Central and Eastern } \\
\text { Europe }\end{array}$ & Saul Estrin & June 1997 \\
\hline $\begin{array}{l}\text { No. 86: Published in : Economics of } \\
\text { Transition, "The Effect of Privatization on } \\
\text { Wealth Distribution in Russia." v. 7, no. 2, } \\
\text { 1999, pp. 449-65 }\end{array}$ & Michael Alexeev & February 1998 \\
\hline $\begin{array}{l}\text { No. 85: Was Privatization in Eastern Germany } \\
\text { a Special Case? Some Lessons from the } \\
\text { Treuhand }\end{array}$ & Uwe Siegmund & September 1997 \\
\hline No. 84: Start-ups and Transition & Daniel M. Berkowitz and David J. Cooper & September 1997 \\
\hline $\begin{array}{l}\text { No. 83: Which Enterprises (Believe They) } \\
\text { Have Soft Budgets after Mass Privatization? } \\
\text { Evidence from Mongolia }\end{array}$ & $\begin{array}{l}\text { James Anderson, Georges Korsun, and } \\
\text { Peter Murrell }\end{array}$ & October 1997 \\
\hline $\begin{array}{l}\text { No. 82: Published in: European Economic } \\
\text { Review, "Unemployment Dynamics and the } \\
\text { Restructuring of the Slovak Unemployment } \\
\text { Benefit System." April, } 1997 .\end{array}$ & Martina Lubyova and Jan C. van Ours & June 1997 \\
\hline $\begin{array}{l}\text { No. 81: Determinants of Unemployment } \\
\text { Duration in Russia }\end{array}$ & Mark C. Foley & August 1997 \\
\hline
\end{tabular}

Working Papers are available at: www.wdi.bus.umich.edu 


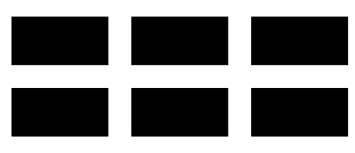

ThE WiLliam DAVIDSON InSTITUTE AT THE UNIVERSITY OF MICHIGAN BUSINESS SCHOOL

\begin{tabular}{|c|c|c|}
\hline $\begin{array}{l}\text { No. 80: The Many Faces of Information } \\
\text { Disclosure }\end{array}$ & Arnoud W.A. Boot and Anjan V. Thakor & October 1997 \\
\hline $\begin{array}{l}\text { No. 79: Published in: Journal of Finance, } \\
\text { "Foreign Speculators and Emerging Equity } \\
\text { Markets."v.22, iss. 2, 2000, pp. 565-613 }\end{array}$ & Geert Bekaert and Campbell R. Harvey & August 1997 \\
\hline $\begin{array}{l}\text { No. 78: The Relationship Between Economic } \\
\text { Factors and Equity Markets in Central Europe }\end{array}$ & Jan Hanousek and Randall K. Filer & June 1997 \\
\hline $\begin{array}{l}\text { No. } 77 \text { Published in: Economics of Transition, } \\
\text { "A Gini Decomposition Analysis of Inequality } \\
\text { in the Czech and Slovak Republics During the } \\
\text { Transition," Vol. 6, No.1, May 1998, pp. 23- } \\
46 .\end{array}$ & Thesia I. Garner and Katherine Terrell & May 1998 \\
\hline $\begin{array}{l}\text { No. 76: China's Emerging Market for Property } \\
\text { Rights: Theoretical and Empirical } \\
\text { Perspectives }\end{array}$ & Gary H. Jefferson and Thomas G. Rawski & June 1997 \\
\hline $\begin{array}{l}\text { No. 75b: Test of Permanent Income } \\
\text { Hypothesis on Czech Voucher Privatization }\end{array}$ & Jan Hanousek and Zdenek Tima & October 1997 \\
\hline $\begin{array}{l}\text { No. 74: Determinants of Performance of } \\
\text { Manufacturing Firms in Seven European } \\
\text { Transition Economies }\end{array}$ & $\begin{array}{l}\text { Stijn Claessens, Simeon Djankov, and } \\
\text { Gerhard Pohl }\end{array}$ & February 1997 \\
\hline $\begin{array}{l}\text { No. } 73 \text { Published in: Economics of Transition, } \\
\text { "The Restructuring of Large Firms in Slovak } \\
\text { Republic." Vol. 6, No. 1, May 1998, pp. 67- } \\
85\end{array}$ & Simeon Djankov and Gerhard Pohl & May 1998 \\
\hline $\begin{array}{l}\text { No. 72: Law, Relationships, and Private } \\
\text { Enforcement: Transactional Strategies of } \\
\text { Russian Enterprises }\end{array}$ & $\begin{array}{l}\text { Kathryn Hendley, Peter Murrell, and Randi } \\
\text { Ryterman }\end{array}$ & November 1998 \\
\hline $\begin{array}{l}\text { No. 71: Giving Credit Where Credit Is Due: } \\
\text { The Changing Role of Rural Financial } \\
\text { Institutions in China }\end{array}$ & Albert Park, Loren Brandt, and John Giles & March 1997 \\
\hline $\begin{array}{l}\text { No. 70: Privatization Versus Competition: } \\
\text { Changing Enterprise Behavior in Russia }\end{array}$ & John S. Earle and Saul Estrin & Spring 1997 \\
\hline $\begin{array}{l}\text { No. 69: Russian Managers under Storm: } \\
\text { Explicit Reality and Implicit Leadership } \\
\text { Theories (A Pilot Exploration) }\end{array}$ & Igor Gurkov & October 1998 \\
\hline $\begin{array}{l}\text { No. 68: The Political Economy of Central- } \\
\text { Local Relations in China: Inflation and } \\
\text { Investment Controls During the Reform Era }\end{array}$ & Yasheng Huang & Spring 1997 \\
\hline $\begin{array}{l}\text { No. 67: Between Two Coordination Failures: } \\
\text { Automotive Industrial Policy in China with a } \\
\text { Comparison to Korea }\end{array}$ & Yasheng Huang & Spring 1997 \\
\hline $\begin{array}{l}\text { No. } 66 \text { Published in: Post-Soviet Geography } \\
\text { and Economics, "Red Executives in Russia's } \\
\text { Transition Economy." Vol. 27, No. 10, } \\
\text { November 1996, pp. 633-651. }\end{array}$ & Susan J. Linz & January 1997 \\
\hline $\begin{array}{l}\text { No. } 65 \text { Published in: Industrial and Corporate } \\
\text { Change, "On the Sequencing of Privatization } \\
\text { in Transition Economies." Vol. 7, No. 1, } \\
1998 .\end{array}$ & Gautam Ahuja and Sumit K. Majumdar & April 1997 \\
\hline $\begin{array}{l}\text { No. 64: Published in: Journal of Law and } \\
\text { Economics, "Foreign Ownership and } \\
\text { Profitability: Property Rights, Control and the }\end{array}$ & $\begin{array}{l}\text { Pradeep K. Chhibber and Sumit K. } \\
\text { Majumdar }\end{array}$ & April 1997 \\
\hline
\end{tabular}

Working Papers are available at: www.wdi.bus.umich.edu 


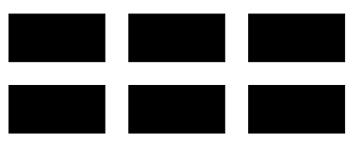

THE WILLIAM DAVIDSON INSTITUTE AT THE UNIVERSITY OF MICHIGAN BUSINESSSCHOOL

\begin{tabular}{|c|c|c|}
\hline $\begin{array}{l}\text { Performance of Firms in Indian Industry" } \\
42(1) \text {, April 1999, pp. 209-38. }\end{array}$ & & \\
\hline $\begin{array}{l}\text { No. 63: How Taxing Is Corruption on } \\
\text { International Investors? }\end{array}$ & Shang-Jin Wei & February 1997 \\
\hline $\begin{array}{l}\text { No. 62: What Can We Learn from the } \\
\text { Experience of Transitional Economies with } \\
\text { Labour Market Policies? }\end{array}$ & Tito Boeri & 1997 \\
\hline $\begin{array}{l}\text { No. 61: Published in: Accounting } \\
\text { Organizations and Society, "Economic } \\
\text { Transition, Strategy and the Evolution of } \\
\text { Management Accounting Practices: The Case } \\
\text { of India" 24(5,6), Jul/Aug 1999, pp. 379-412. }\end{array}$ & $\begin{array}{l}\text { Shannon W. Anderson and William N. } \\
\text { Lanen }\end{array}$ & April 1997 \\
\hline $\begin{array}{l}\text { No. 60a: Enterprise Investment During the } \\
\text { Transition: Evidence from Czech Panel Data }\end{array}$ & Lubomír Lizal and Jan Svejnar & December 1997 \\
\hline $\begin{array}{l}\text { No. 59: Published in: Journal of Law, } \\
\text { Economics, and Organization, "Institutional } \\
\text { Environment, Community Government, and } \\
\text { Corporate Governance: Understanding } \\
\text { China's Township-Village Enterprises." 14(1), } \\
\text { April 1998, pages 1-23 }\end{array}$ & Jiahua Che and Yingyi Qian & April 1997 \\
\hline $\begin{array}{l}\text { No. 58: From the Grabbing Hand to the } \\
\text { Helping Hand }\end{array}$ & Jiahua Che & June 2000 \\
\hline $\begin{array}{l}\text { No. 57: Published in: Brookings Papers on } \\
\text { Economic Activity, "The Unofficial Economy } \\
\text { in Transition." 1: 1998. }\end{array}$ & $\begin{array}{l}\text { Simon Johnson, Daniel Kaufmann, and } \\
\text { Andrei Schleifer }\end{array}$ & June 1997 \\
\hline $\begin{array}{l}\text { No. 56: Taxes and Government Incentives: } \\
\text { Eastern Europe vs. China }\end{array}$ & Roger H. Gordon and David D. Li & April 1997 \\
\hline No. 55: Corruption and Reform & Susanto Basu and David Li & June 1996 \\
\hline $\begin{array}{l}\text { No. 54: Decentralization and the } \\
\text { Macroeconomic Consequences of } \\
\text { Commitment to State-Owned Firms }\end{array}$ & Loren Brandt and Xiaodong Zhu & June 1997 \\
\hline $\begin{array}{l}\text { No. 53: Published in: The International } \\
\text { Journal of Industrial Organization, } \\
\text { "Competitive Shocks and Industrial Structure: } \\
\text { The Case of Polish Manufacturing." August, } \\
\text { 1999. . }\end{array}$ & Pankaj Ghemawat and Robert E. Kennedy & May 1997 \\
\hline $\begin{array}{l}\text { No. 52: Published in: The Quarterly Journal of } \\
\text { Economics, "Insecure Property Rights and } \\
\text { Government Ownership of Firms." May, } \\
1998 .\end{array}$ & Jiahua Che and Yingyi Qian & May 1997 \\
\hline $\begin{array}{l}\text { No. 51: Incentives, Scale Economies, and } \\
\text { Organizational Form }\end{array}$ & $\begin{array}{l}\text { Eric Maskin, Yingyi Qian, and Chenggang } \\
\mathrm{Xu}\end{array}$ & May 1997 \\
\hline $\begin{array}{l}\text { No. 50: Published in: Post-Soviet-Affairs, } \\
\text { "End of the Tunnel? The Effects of Financial } \\
\text { Stabilization in Russia" April-June 1997, } \\
\text { pages 105-33 }\end{array}$ & $\begin{array}{l}\text { Barry W. Ickes, Peter Murrell, and Randi } \\
\text { Ryterman }\end{array}$ & March 1997 \\
\hline $\begin{array}{l}\text { No. 49: The Evolution of Bank Credit Quality } \\
\text { in Transition: Theory and Evidence from } \\
\text { Romania }\end{array}$ & Enrico C. Perotti and Octavian Carare & October 1996 \\
\hline $\begin{array}{l}\text { No. 48: Where Do the Leaders Trade? } \\
\text { Information Revelation and Interactions } \\
\text { Between the Segments of Czech Capital }\end{array}$ & Jan Hanousek and Libor Nemecek & May 1997 \\
\hline
\end{tabular}

Working Papers are available at: www.wdi.bus.umich.edu 


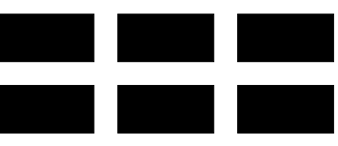

THE WILLIAM DAVIDSON INSTITUTE AT THE UNIVERSITY OF MICHIGAN BUSINESSSCHOOL

\begin{tabular}{|c|c|c|}
\hline Markets & & \\
\hline $\begin{array}{l}\text { No. 47: Firms' Heterogeneity in Transition: } \\
\text { Evidence from a Polish Panel Data Set }\end{array}$ & Irena Grosfeld and Jean-François Nivet & May 1997 \\
\hline $\begin{array}{l}\text { No. 46: Strategic Creditor Passivity, } \\
\text { Regulation, and Bank Bailouts }\end{array}$ & Janet Mitchell & May 1997 \\
\hline $\begin{array}{l}\text { No. 45a: Published in: Journal of Public } \\
\text { Economics, "Tax Rights in Transition } \\
\text { Economies: A Tragedy of the Commons." 76, } \\
\text { 2000, pp. 369-397 }\end{array}$ & Daniel M. Berkowitz and Wei Li & September 1997 \\
\hline $\begin{array}{l}\text { No. 44a: The Information Content of Stock } \\
\text { Markets: Why do Emerging Markets have } \\
\text { Synchronous Stock Price Movements? } \\
\text { (forthcoming in the Journal of Financial } \\
\text { Economics). }\end{array}$ & $\begin{array}{l}\text { Randall Morck, Bernard Yeung, and } \\
\text { Wayne Yu }\end{array}$ & February 1999 \\
\hline $\begin{array}{l}\text { No. 43: Agency in Project Screening and } \\
\text { Termination Decisions: Why Is Good Money } \\
\text { Thrown After Bad? }\end{array}$ & Chong-en Bai and Yijiang Wang & May 1997 \\
\hline $\begin{array}{l}\text { No. 42: Published in: Economics of } \\
\text { Transition, "Channels of Redistribution: } \\
\text { Inequality and Poverty in the Russian } \\
\text { Transition." Vol. } 7 \text { (2) } 1999 .\end{array}$ & $\begin{array}{l}\text { Simon Commander, Andrei } \\
\text { Tolstopiatenko, and Ruslan Yemtsov }\end{array}$ & May 1997 \\
\hline $\begin{array}{l}\text { No. 41: Published in: Economics of } \\
\text { Transition, "Labour Market Characteristics } \\
\text { and Profitability: Econometric Analysis of } \\
\text { Hungarian Exporting Firms, 1986-1995" 6(1), } \\
\text { May 1998, pages 145-62 }\end{array}$ & László Halpern and Gabor Korosi & May 1997 \\
\hline $\begin{array}{l}\text { No. 40: Published in: the Harvard Law } \\
\text { Review, "The Tragedy of the Anticommons: } \\
\text { Property in the Transition from Marx to } \\
\text { Markets." January } 1998 \text {. }\end{array}$ & Michael Heller & February 1997 \\
\hline $\begin{array}{l}\text { No. 39: Privatization and Managerial } \\
\text { Efficiency }\end{array}$ & Olivier Debande and Guido Friebel & May 1997 \\
\hline $\begin{array}{l}\text { No. } 38 \text { Published in: The Quarterly Journal of } \\
\text { Economics, "Disorganization." Vol. 112, No. } \\
\text { 4, November 1997, pp. 1091-1126. }\end{array}$ & Olivier Blanchard and Michael Kremer & January 1997 \\
\hline $\begin{array}{l}\text { No. 37: Published in: Economics of } \\
\text { Transition, "Transition and the Output Fall." } \\
7(1), 1999 \text {, pages 1-28. }\end{array}$ & Gérard Roland and Thierry Verdier & March 1997 \\
\hline $\begin{array}{l}\text { No. 36: Restructuring an Industry During } \\
\text { Transition: A Two-Period Model }\end{array}$ & Richard Ericson & September 1996 \\
\hline $\begin{array}{l}\text { No. 34: The East-West Joint Venture: BC } \\
\text { Torsion Case Study }\end{array}$ & Sonia Ferencikova and Vern Terpstra & December 1998 \\
\hline $\begin{array}{l}\text { No. } 33 \text { Published in: Journal of Comparative } \\
\text { Economics, "Quantifying Price Liberalization } \\
\text { in Russia." Vol. 26, No. 4, December 1998, } \\
\text { pp. 735-737. }\end{array}$ & $\begin{array}{l}\text { Daniel Berkowitz, David DeJong, and } \\
\text { Steven Husted }\end{array}$ & December 1998 \\
\hline $\begin{array}{l}\text { No. 32: What Can North Korea Learn from } \\
\text { China's Market Reforms? }\end{array}$ & John McMillan & September 1996 \\
\hline $\begin{array}{l}\text { No. 31: Published in : China-Economic- } \\
\text { Review, "Towards a Model of China as a } \\
\text { Partially Reformed Developing Economy } \\
\text { Under a Semifederalist Government.", 9(1), }\end{array}$ & Yijiang Wang and Chun Chang & March 1997 \\
\hline
\end{tabular}

Working Papers are available at: www.wdi.bus.umich.edu 


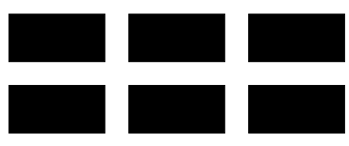

THE WILLIAM DAVIDSON INSTITUTE

AT THE UNIVERSITY OF MICHIGAN BUSINESSSCHOOL

\begin{tabular}{|c|c|c|}
\hline Spring 1998, pages 1-23. & & \\
\hline $\begin{array}{l}\text { No. 30: Convergence in Output in Transition } \\
\text { Economies: Central and Eastern Europe, } \\
\text { 1970-1995 }\end{array}$ & Saul Estrin and Giovanni Urga & February 1997 \\
\hline $\begin{array}{l}\text { No. 29: Published in: Economics of } \\
\text { Transition, "Altered Band and Exchange } \\
\text { Volatility." Volume 6, no. 1, 1998, 173-181. }\end{array}$ & Evzen Kocenda & March 1997 \\
\hline $\begin{array}{l}\text { No. 28: Published in: Quarterly Journal of } \\
\text { Economics, "Public Versus Private Ownership } \\
\text { of Firms: Evidence from Rural China." } \\
\text { Volume 113, no. 3, August 1998, 773-808. }\end{array}$ & Hehui Jin and Yingyi Qian & January 1997 \\
\hline $\begin{array}{l}\text { No. 27: East-West Joint Ventures in a } \\
\text { Transitional Economy: The Case of Slovakia }\end{array}$ & Sonia Ferencikova & March 1997 \\
\hline $\begin{array}{l}\text { No. 26: Published in Economic Analysis } \\
\text { "Behavior of a Slovenian Firm in Transition" } \\
\text { Vol. 1, no. 1, 1998, 57-73. }\end{array}$ & Janez Prasnikar & February 1997 \\
\hline $\begin{array}{l}\text { No. 25: Cultural Encounters and Claims to } \\
\text { Expertise in Postcommunist Capitalism }\end{array}$ & Michael D. Kennedy & February 1997 \\
\hline $\begin{array}{l}\text { No. 24: ZVU a.s.: Investment Funds on the } \\
\text { Board of Directors of an Engineering Giant }\end{array}$ & Tory Wolff & August 1995 \\
\hline $\begin{array}{l}\text { No. 23: The Role of Investment Funds in the } \\
\text { Czech Republic (joint publication with Czech } \\
\text { Management Center) }\end{array}$ & Dusan Triska & June 1996 \\
\hline $\begin{array}{l}\text { No. 22: Czech Investment Fund Industry: } \\
\text { Development and Behaviour (joint publication } \\
\text { with Czech Management Center) }\end{array}$ & Richard Podpiera & May 1996 \\
\hline $\begin{array}{l}\text { No. 21: Restructuring of Czech Firms: An } \\
\text { Example of Gama, a.s. (joint publication with } \\
\text { Czech Management Center) }\end{array}$ & Antonin Bulin & June 1996 \\
\hline $\begin{array}{l}\text { No. 20: YSE Funds: A Story of Czech } \\
\text { Investment Funds (joint publication with } \\
\text { Czech Management Center) }\end{array}$ & Michal Otradovec & November 1995 \\
\hline $\begin{array}{l}\text { No. 19: První Investicni a.s., The First } \\
\text { Investment Corporation (joint publication } \\
\text { with Czech Management Center) }\end{array}$ & Jaroslav Jirasek & August 1995 \\
\hline $\begin{array}{l}\text { No. 18: PPF a.s., The First Private Investment } \\
\text { Fund (joint publication with Czech } \\
\text { Management Center) }\end{array}$ & Michal Otradovec & November 1995 \\
\hline $\begin{array}{l}\text { No. } 17 \text { Published in: Post-Soviet Geography } \\
\text { and Economics, "Russia's Managers in } \\
\text { Transition: Pilferers or Paladins?" Vol. 37, } \\
\text { o.7 (September 1996), pp. 397-426. }\end{array}$ & Susan J. Linz and Gary Krueger & November 1996 \\
\hline $\begin{array}{l}\text { No. 16: Banks in Transition-Investment } \\
\text { Opportunities in Central Europe and Russia } \\
\text { Edited Transcript from } 31 \text { May } 1996 \\
\text { Conference in New York City }\end{array}$ & $\begin{array}{l}\text { With commentary and edited by Anna } \\
\text { Meyendorff }\end{array}$ & January 1997 \\
\hline $\begin{array}{l}\text { No. 15: Marketing in Transitional Economies: } \\
\text { Edited Transcript \& Papers from } 1 \text { April } 1996 \\
\text { Conference in Ann Arbor, Michigan }\end{array}$ & Compiled by The Davidson Institute & December 1996 \\
\hline $\begin{array}{l}\text { No. 14: Pensions in the Former Soviet Bloc: } \\
\text { Problems and Solutions. Published by } \\
\text { Council on Foreign Relations. "The Coming }\end{array}$ & Jan Svejnar & November 1996 \\
\hline
\end{tabular}

Working Papers are available at:

www.wdi.bus.umich.edu 


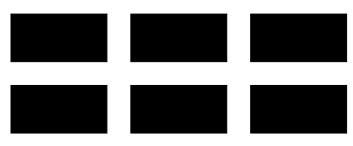

THE WILLIAM DAVIDSON INSTITUTE AT THE UNIVERSITY OF MICHIGAN BUSINESSSCHOOL

\begin{tabular}{|c|c|c|}
\hline Global Pension Crisis" New York, 1997 & & \\
\hline $\begin{array}{l}\text { No. 13: Enterprise Restructuring and } \\
\text { Performance in the Transition. Forthcoming } \\
\text { in Financial Systems in Transition: The } \\
\text { Design of Financial Systems in Central } \\
\text { Europe eds. Anna Meyendorff and Anjan } \\
\text { Thakor. }\end{array}$ & $\begin{array}{l}\text { Lubomir Lizal, Miroslav Singer, and Jan } \\
\text { Svejnar }\end{array}$ & December 1996 \\
\hline $\begin{array}{l}\text { No. } 12 \text { Published in: Journal of International } \\
\text { Marketing, "Executive Insights: Marketing } \\
\text { Issues and Challenges in Transitional } \\
\text { Economies." Vol. 5, No. 4, 1997, pp. 95-114. } \\
\text { Also published in: Marketing Issues in } \\
\text { Transitional Economies ed. Rajeev Batra. }\end{array}$ & Rajeev Batra & April 1997 \\
\hline $\begin{array}{l}\text { No. 11: Worker Trust and System } \\
\text { Vulnerability in the Transition from Socialism } \\
\text { to Capitalism }\end{array}$ & Andrew Schotter & August 1996 \\
\hline $\begin{array}{l}\text { No. } 10 \text { Published in: Comparative Economic } \\
\text { Studies, "Russian Firms in Transition: } \\
\text { Champions, Challengers, and Chaff." Vol. 39, } \\
\text { No.2, Summer 1997, pp. 1-36. }\end{array}$ & Susan J. Linz & July 1996 \\
\hline $\begin{array}{l}\text { No. 9: Corporate Debt Crisis and Bankruptcy } \\
\text { Law During the Transition: The Case of China }\end{array}$ & David D. Li and Shan Li & December 1995 \\
\hline $\begin{array}{l}\text { No. } 8 \text { Published in: Journal of Comparative } \\
\text { Economics, “A Theory of Ambiguous } \\
\text { Property Rights in Transition Economies: The } \\
\text { Case of the Chinese Non-State Sector." Vol. } \\
\text { 23, No. 1, August 1996, pp. 1-19. }\end{array}$ & David D. Li & June 1996 \\
\hline $\begin{array}{l}\text { No. 7: The Foreign Economic Contract Law of } \\
\text { China: Cases and Analysis }\end{array}$ & Dong-lai Li & June 1993 \\
\hline $\begin{array}{l}\text { No. 3: Bank Privatization in Hungary and the } \\
\text { Magyar Kulkereskedelmi Bank Transaction }\end{array}$ & Roger Kormendi and Karen Schnatterly & May 1996 \\
\hline $\begin{array}{l}\text { Replacing Nos. 1-2 \& 4-6: Journal of } \\
\text { Comparative Economics Symposium on } \\
\text { "Bank Privatization in Central Europe and } \\
\text { Russia." Vol. 25, No. 1, August } 1997 .\end{array}$ & $\begin{array}{l}\text { No. } 1 \text { "Bank Privatization in Transitional } \\
\text { Economies" by Roger Kormendi and } \\
\text { Edward Snyder. No. } 2 \text { "Transactional } \\
\text { Structures of Bank Privatizations in } \\
\text { Central Europe and Russia" by Anna } \\
\text { Meyendorff and Edward A. Snyder. No. } 4 \\
\text { "Bank Privatization in Poland: The Case of } \\
\text { Bank Slaski" by Jeffery Abarbaness and } \\
\text { John Bonin. No. } 5 \text { "Bank Privatization in } \\
\text { Post-Communist Russia: The Case of } \\
\text { Zhilsotsbank" by Jeffery Abarbanell and } \\
\text { Anna Meyendorff and No. } 6 \text { "'The Czech } \\
\text { Republic's Commercial Bank: Komercni } \\
\text { Banka" by Edward A. Snyder and Roger } \\
\text { C. Kormendi. }\end{array}$ & August 1997 \\
\hline
\end{tabular}

Working Papers are available at: www.wdi.bus.umich.edu 